\title{
Is the Awareness of the Aerosol State Useful in Predicting Enhanced Lightning for Lightning-Producing Storms over Northern Alabama?
}

\author{
TONG REN, ANITA D. RAPP, AND SHAIMA L. NASIRI ${ }^{\mathrm{a}}$ \\ Department of Atmospheric Sciences, Texas A\&M University, College Station, Texas \\ JoHn R. MECIKALSKI AND JASON APKE \\ Atmospheric Science Department, University of Alabama in Huntsville, Huntsville, Alabama
}

(Manuscript received 27 June 2017, in final form 18 March 2018)

\begin{abstract}
The Moderate Resolution Imaging Spectroradiometer (MODIS) aerosol optical depth (AOD) retrievals from the Terra and Aqua satellites currently provide the largest satellite aerosol dataset for investigating relationships to meteorological phenomena, such as aerosol impact on electrification in deep convection. The usefulness of polar-orbiting satellite aerosol retrievals in lightning inference is examined by correlating MODIS AOD retrievals with lightning observations of the thunderstorms in the summers during 2002-14 over northern Alabama. Lightning flashes during the 1400-1700 local standard time peak period show weak but positive correlations with the MODIS AOD retrievals $2-4 \mathrm{~h}$ earlier. The correlation becomes stronger in particular meteorological conditions, including weak vertical wind shear and prevailing northerly winds over northern Alabama. Results show that the MODIS AOD retrievals are less useful in predicting enhanced lightning flash rate for lightning-producing storms than the forecasts of other meteorological variables that are more closely linked to the intensification of convective storms. However, when relatively weaker convective available potential energy (CAPE) is forecast, the probability of enhanced lightning flash rate increases in a more polluted environment, making the knowledge of aerosols more useful in lightning inference in such CAPE regimes. The aerosol enhancement of lightning, if present, may be associated with enhanced convergence in the boundary layer and secondary convection.
\end{abstract}

\section{Introduction}

From 2005 to 2014, on average, lightning resulted in 30 fatalities (Holle 2016) in the United States. A previous study has shown that 19814 cases of property damage from lightning were reported in the United States from 1959 to 1994 , and the annual mean lightning damage from 1992 to 1994 was $\sim 32$ million dollars (Curran et al. 2000). Improving lightning forecasts could help mitigate these threats to life and property.

In a thunderstorm, collisions between ice crystals and graupel particles in the presence of supercooled liquid water transfer positive charge to the particle that is growing the fastest (Saunders et al. 2006; Williams et al. 1991). Charge regions then form through differential

\footnotetext{
${ }^{a}$ Current affiliation: Office of Biological and Environmental Research, U.S. Department of Energy, Washington, D.C.
}

Corresponding author: Tong Ren,tr7585@tamu.edu sedimentation of the ice and graupel in a strong updraft, and they discharge in the form of lightning when the electric field reaches the atmospheric breakdown limit. Both the updrafts of a thunderstorm and aerosols in the boundary layer can contribute to changes in the hydrometeor microphysics and hence the magnitude of lightning activity (Mansell and Ziegler 2013; Williams et al. 2002). An adequately strong updraft is necessary for the rapid electrification of a convective cell, presumably because of the promoted particle growth and ice-graupel collisions in the presence of supercooled water, as somewhat evidenced by the enhanced radarmeasured precipitation and nonprecipitation ice mass fluxes (Deierling et al. 2008). With typically higher convective available potential energy (CAPE) upon initiation, the updrafts of continental deep convection are generally stronger than oceanic deep convection (C. Liu et al. 2007), which may account for the observation that more lightning events occur over continents than over oceans (e.g., Cecil et al. 2014; Christian et al. 2003; Zipser 1994). 
More recent studies suggest that an increase in updraft volume rather than maximum updraft speed is the primary contributor to rapid increases in total lightning flash rate on an individual storm basis (Deierling and Petersen 2008; Schultz et al. 2017), although updraft volume and speed are related.

A number of studies have also hypothesized relationships between aerosols ingested into convection and the total lightning. Aerosols can suppress the rainfall during the warm rain phase of deep convection by reducing the droplet size, which limits collision and coalescence (e.g., Albrecht 1989; Feingold 2003), and the resultant increased number of particles may be lifted above the freezing level (e.g., Andreae et al. 2004; Khain et al. 2005; van den Heever et al. 2006). Consequently, like the effects of a strong updraft, increased supercooled water may reinforce the growth of ice particles, increasing the effectiveness of the noninductive charging process (Williams et al. 2002). Many observational studies have reported increased lightning activity with increased aerosol ingestion (Albrecht et al. 2011; Altaratz et al. 2010, 2014; Orville et al. 2001; Proestakis et al. 2016a,b; Stolz et al. 2015, 2017; Storer et al. 2014; Wang et al. 2011; Yuan et al. 2011, 2012). A 12-yr record of flash density over the Houston, Texas, area shows a high frequency of summer lightning activity over the urban and downstream areas of Houston as compared to nearby oceanic regions, which may be in part due to the increased air pollutants from urbanization (Orville et al. 2001) and the petroleum refinery capacity (Steiger et al. 2002). Naccarato et al. (2003) suggested that both urban heat island and aerosol effects contribute to the increased cloud-to-ground (CG) lightning flashes over three large metropolitan areas in southeastern Brazil. Stolz et al. (2015) suggest that increased lightning rate densities are associated with high normalized CAPE values in combination with high cloud condensation nuclei $(\mathrm{CCN})$ concentrations over the tropics. Stolz et al. (2017) show that total lightning density increases with increasing normalized CAPE, increasing CCN concentration, decreasing warm cloud depth, increasing vertical wind shear, and decreasing relative humidity. Positive correlations between aerosol loading and lightning flashes were found at interannual time scales over the west Pacific Ocean (Yuan et al. 2011), the Pearl River delta megacity area in China (Wang et al. 2011), and the major urban areas in South Korea (Kar et al. 2009). Increased aerosol particles from the exhaust of ships are coincident with enhanced lightning strike rate density over the shipping lanes in the eastern Indian Ocean and the South China Sea (Thornton et al. 2017). However, such positive correlations are not present everywhere (Altaratz et al. 2010; Coquillat et al. 2013; Williams et al. 2002).
For example, it appears that the impact of pollutants on lightning activity may be more significant downwind of Paris, France, than over the surrounding areas (Coquillat et al. 2013). Van den Heever and Cotton (2007) suggested that the development of storms downwind of Saint Louis, Missouri, is determined by the urban-force convergence rather than the presence of increased aerosols concentrations.

This aerosol-lightning relationship has also been explored during the premonsoon season over the Amazon (Williams et al. 2002). Though thunderstorms tend to occur during periods of relatively higher aerosol concentration in the Amazonian wet season (Albrecht et al. 2011), the radiative forcing of smoke aerosols during the dry season may stabilize the lower troposphere and thus inhibit deep convection and cloud electrification (Altaratz et al. 2010). Morales Rodriguez et al. (2010) suggested no significant aerosol effect on the development of thunderstorms in austral summer over São Paulo, Brazil. Tan et al. (2016) show a negative correlation between monthly mean aerosol optical depth (AOD) and lightning flash density over Nanjing, China. The coupling between microphysics and dynamics has been surveyed by Altaratz et al. (2014) in the context of convection invigoration by aerosols. Previous studies have shown that whether aerosols enhance or suppress convection is dependent on meteorological conditions (e.g., Albrecht et al. 2011; Fan et al. 2009; Storer et al. 2014, 2010). Fan et al. (2009) suggest that in the presence of weak wind shear, increased aerosols invigorate isolated deep convection, and the invigoration maximizes as $\mathrm{CCN}$ concentration reaches $500 \mathrm{~cm}^{-3}$ or higher in their model simulations. In the presence of strong wind shear, increased aerosols may suppress isolated deep convection (Fan et al. 2009). The suppression is even stronger in a more humid environment with a higher CAPE (Fan et al. 2009). Aerosols can modulate the storm response to different forcings, where the storm response to forcings is also affected by available CAPE (Storer et al. 2010). Hence, the aerosol impact on lightning may vary at different locations and times. Parameterizations have been suggested for modeling lightning (e.g., Mansell and Ziegler 2013; Mansell et al. 2010), where the meteorological conditions can be controlled to study the aerosol effects on lightning features (e.g., Wang et al. 2011). Although numerous studies have focused on the linkage between aerosols and lightning, whether aerosol observations are helpful for lightning prediction remains unclear.

Numerous observational studies have compared lightning to radar characteristics of storms (Bringi et al. 1997; Byers and Braham 1949; Carey and Rutledge 1996, 2000; Dye et al. 1986; Goodman et al. 1988; 
Larsen and Stansbury 1974; Marshall and Radhakant 1978; Schultz et al. 2011, 2017; Williams et al. 1989). An exponential growth (or the maximum growth rate) of precipitation ice volume often peaks prior to the peak occurrence of lightning flash rate (FR), with as much as a 20-min time lag (Carey and Rutledge 1996; Goodman et al. 1988), and this feature has been used for lightning forecasts (Mosier et al. 2011; Vincent et al. 2004) and severe weather warnings (Gatlin and Goodman 2010; Schultz et al. 2011, 2017). A radar-measured 40-dBZ intensity echo at the $-10^{\circ} \mathrm{C}$ isotherm was found as the best indicator of $\mathrm{CG}$ lightning with a mean lead time of 14.7 min over central North Carolina (Vincent et al. 2004). A trade-off between lead time and false alarm rate can be readily made by tuning the radar echo threshold (Vincent et al. 2004). Vertically integrated ice, a new radar-derived product, has been developed for improving lightning nowcasts over Houston (Mosier et al. 2011). Simulations from a cloud-resolving model have been used for forecasting lightning threat, but the accuracy of this method is restricted by the model incapability of predicting the instantaneous locations of a storm (McCaul et al. 2009). In addition, synoptic map analyses - such as the forecast 18 - and 30-h sea level pressure fields - are useful for analyzing the distribution of thunderstorms and thus lightning over an area (Reap 1994). Moreover, regional geostationary satellite and radar observations in advance of first-flash lightning have been documented (Harris et al. 2010; Mecikalski et al. 2013).

Although various techniques have been used for forecasting lightning formation, to the best of our knowledge, none of these techniques has included satellite aerosol retrievals in prediction. The objective of this study is to examine if satellite aerosol retrievals are useful for prediction of enhanced lightning in lightning-producing storms. The objective is achieved by the following: 1) examine if the aerosol products currently available can be used for potential lightning inferences, in terms of FRs; and 2) determine how useful the aerosol state in statistical inference models is compared to the forecast of other meteorological variables in the context of enhanced lightning FR inferences.

\section{Data and methodology}

\section{a. Lightning flashes}

This study focuses on the northern Alabama region of the United States where lightning data have been collected and archived by the North Alabama Lightning Mapping Array (NALMA) since 2002 (Goodman et al. 2005; Koshak et al. 2004). Total (intracloud and cloud-toground) lightning flashes are derived (McCaul et al. 2005) from the NALMA very high-frequency (VHF) source data for each June-August (JJA) time period when lightning is most active (e.g., Albrecht et al. 2016; Christian et al. 2003). The detection efficiency of the NALMA is a function of distance and azimuthal angle (Chmielewski and Bruning 2016). Figure 1 shows the distributions of the mean FR during 1400-1700 local standard time (LST) in JJA from 2002 to 2014 over northern Alabama. The LST is $6 \mathrm{~h}$ behind the coordinated universal time (UTC), that is, LST = UTC - 0600. Because the location uncertainty of the VHF sources increases with distance (Thomas et al. 2004), we show only the flashes that occurred within a circle centered at the LMA network with a radius of $150 \mathrm{~km}$, where the detection efficiency is greater than 90\% (Chmielewski and Bruning 2016).

Only lightning events that are detected by at least 6 stations are archived by LMAs (Rison et al. 1999). The FR distributions shown in Figs. 1a-d were filtered using different thresholds of station numbers. In agreement with the recent study of Chmielewski and Bruning (2016), the NALMA detection efficiency is dependent upon the azimuthal angle and distance (Fig. 1). Because the following analyses are based on the lightning statistics of individual storm samples averaged over the circle centered at the NALMA with a radius of $150 \mathrm{~km}$, the bias in detected flashes that results from the detection efficiency variation does not affect the results. Use of an increased station number threshold may remedy the azimuthal variability of detected lightning flashes, but it also could reduce the number of identified flash events, and thus a trade-off must be made.

We selected the flashes that were detected by at least seven stations for reducing the difference between the detection efficiencies of the NALMA at the center and edge of the study area. As shown in Fig. 1b, although the azimuthal variability is not completely removed, an adequate number of flash events is retained for statistical analysis. However, Figs. 1c and 1d show that if only the strongest flash events are used, then no flashes are identified in parts of the circular area. Specifying such stringent criteria would preclude the analysis of storms with lower FRs.

\section{b. Satellite and ground-based aerosol retrievals}

Aerosol conditions in terms of AOD can be retrieved globally from satellite observations. Currently, the Multiangle Imaging SpectroRadiometer (MISR), the Moderate Resolution Imaging Spectroradiometer (MODIS), and the Ozone Monitoring Instrument (OMI) on board the Aqua and Terra satellites have more than $10 \mathrm{yr}$ of aerosol retrievals, which can be used to study the potential of applying satellite aerosol retrievals for lightning prediction. Unlike MODIS and MISR, OMI is not designed for aerosol retrievals. OMI aerosol 
(a) Flashes detected by $>6$ detectors

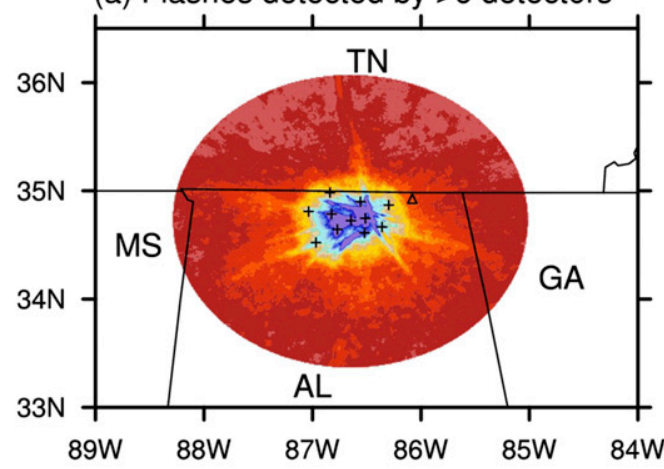

(c) Flashes detected by $>8$ detectors

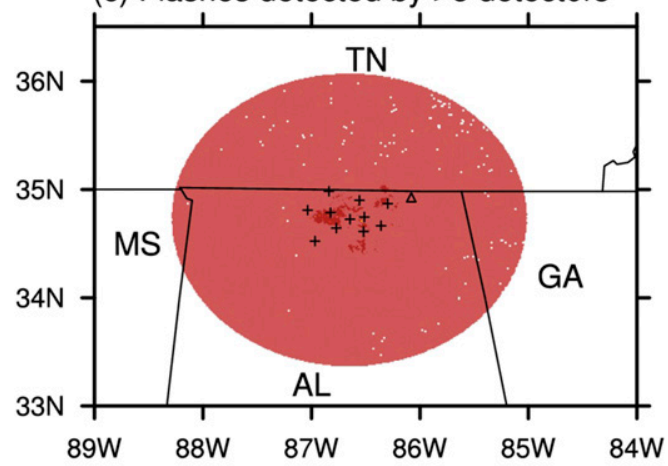

(b) Flashes detected by $>7$ detectors

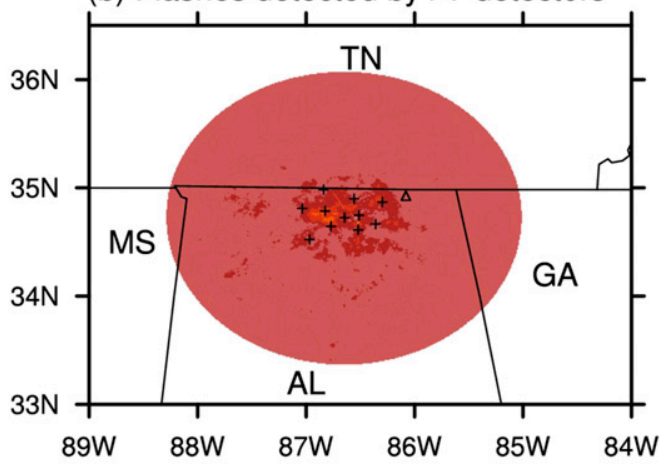

(d) Flashes detected by $>9$ detectors

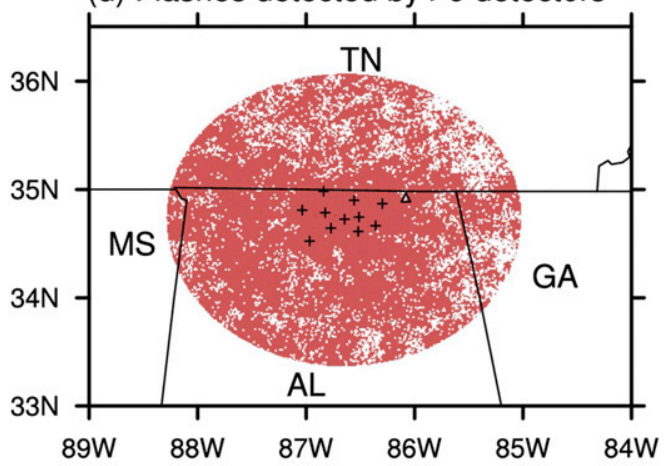

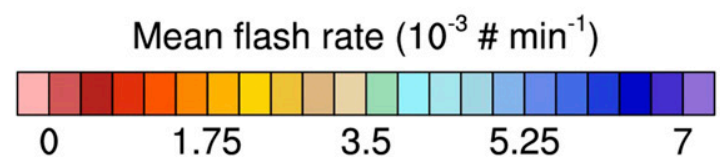

FIG. 1. Distributions of the mean flash rate $\left(10^{-3} \times\right.$ flashes per minute $)$ during $1400-1700$ LST in JJA from 2002 to 2014 over northern Alabama. The flashes were detected by at least (a) 6, (b) 7, (c) 8, and (d) 9 stations. For example, the flash events in (a) are detected by 6 or more stations, while the flash events in (b) were detected by 7 or more stations. The borders of Alabama (AL), Georgia (GA), Mississippi (MS), and Tennessee (TN) are shown. The plus signs show the detector locations of the NALMA. The triangle is the location of the NEXRAD KHTX site.

products contain AOD at satellite channel wavelengths 354,388 , and $500 \mathrm{~nm}$, among which the 500-nm AOD is derived by extrapolation and hence is of a lower accuracy (Livingston et al. 2009). The swath of aerosols retrievals from MISR (Martonchik and Diner 1992; Martonchik et al. 1998) is $360 \mathrm{~km}$ wide, while the swath of MODIS aerosol retrievals (Levy et al. 2007a,b) is $2330 \mathrm{~km}$ wide. Depending on the latitude, MODIS and MISR have global coverage of 1-2 and 2-9 days, respectively (e.g., Y. Liu et al. 2007). In other words, during a period such as a week during summer, MODIS aerosol retrievals are available more frequently than MISR aerosol retrievals, and hence MODIS provides more samples than MISR for studying the usefulness of aerosol retrievals in statistical models of lightning inferences.

The presence of aerosols over the dark surface scatters more incident solar radiation back to space. The
MODIS aerosol retrieval algorithm makes use of the observations from two visible $(0.47$ and $0.66 \mu \mathrm{m})$ and one near-infrared $(2.12 \mu \mathrm{m})$ channels to detect aerosol signals, where empirical relationships between the surface reflectance at $2.12 \mu \mathrm{m}$ and the ones at the two visible bands are assumed (Levy et al. 2007a,b). AOD is a column-averaged quantity. Theoretically, all the layers of aerosol particles in the vertical atmospheric column contribute to the backscattered solar radiation received by the sensor. In the atmosphere, often most aerosol particles are within the planetary boundary layer (PBL) and the aerosol concentration decreases exponentially with height above the PBL (e.g., He et al. 2008). MODIS AOD retrievals can characterize the aerosol loading within the PBL but cannot resolve their vertical distribution. Moreover, MODIS AOD retrievals only apply to clear-sky conditions. AOD cannot be retrieved from the MODIS measurements if there is a cloud. Both the 


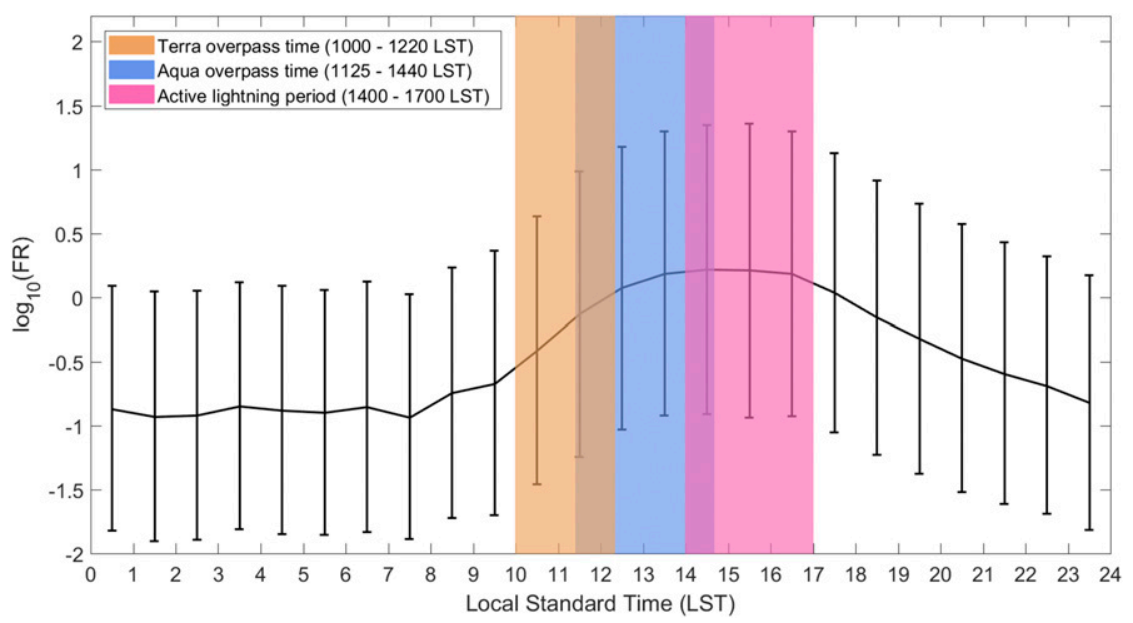

FIG. 2. Mean diurnal variation of the logarithm (base 10) of flash rate in JJA from 2002 to 2014 over northern Alabama. The error bars show the standard deviations. The pink-shaded area shows the active lightning period, the brown-shaded area shows the range of the Terra satellite overpass times, and the blue-shaded area shows the range of the Aqua satellite overpass times.

3-km spatial resolution Collection 6 Terra and Aqua MODIS L2_04 aerosol retrievals (Levy et al. 2013) are used for this study.

In the daytime, the Terra satellite passes northern Alabama around noon, and the Aqua satellite passes northern Alabama in the early afternoon. If the storms occur a long period after the satellite overpass, then the MODIS AOD retrievals may not represent the aerosol conditions when the storms occur, because aerosol properties change over time (C. Liu et al. 2011; Smirnov et al. 2002). Fortunately, lightning flash rate generally peaks in the late afternoon over continents (Blakeslee et al. 2014; Williams and Heckman 1993). Over North America, the annual flash rate peaks at 1500 LST (Blakeslee et al. 2014), a few hours later than the Terra and Aqua overpass times. Figure 2 shows the averaged diurnal variation of the logarithm base 10 of FR [ $\left.\log _{10}(\mathrm{FR})\right]$ for JJAs from 2002 to 2014 over northern Alabama. As shown in Fig. $2, \log _{10}(\mathrm{FR})$ peaks around 1400-1700 LST, in agreement with previous studies (Blakeslee et al. 2014; Williams and Heckman 1993). The diurnal variation of $\log _{10}(\mathrm{FR})$ suggests that most lightning events occur a few hours after the satellite overpass times. Therefore, this study focuses on the most active lightning period 1400-1700 LST right after the Aqua satellite overpass time.

It has been reported that the uncertainty of MODIS AOD retrievals over land is about $\pm 0.05 \pm 0.20 \times \mathrm{AOD}$ with a root-mean-square error (RMSE) less than 0.1 (Chu et al. 2002). To assess whether the MODIS AOD errors are small enough to be useful for this study, the MODIS AOD retrievals in 2008 and 2009 are compared with the Aerosol Robotic Network (AERONET; Holben et al. 1998) Level 2.0 AOD data from the University of Alabama in Huntsville (UAH) site $\left(34^{\circ} 43^{\prime} 30^{\prime \prime} \mathrm{N}, 86^{\circ} 38^{\prime} 42^{\prime \prime} \mathrm{W}\right)$, which are cloud screened and quality assured. AERONET is a network of sun photometers, which point directly at the sun. AOD can be retrieved from the sun photometer measurement of sunlight attenuation along the atmospheric path if it is clear of clouds. Ichoku et al. (2002) suggested that a $50 \times 50 \mathrm{~km}^{2}$ air mass captured by MODIS over a sun photometer site will be sampled by the sun photometer during $1 \mathrm{~h}$, and the correlations decrease as the area increases (Kovacs 2006). We compare the averaged MODIS aerosol retrievals over a circle centered on the UAH site with a radius of $50 \mathrm{~km}$ with the AERONET AODs averaged $30 \mathrm{~min}$ before and after the satellite overpass time. The AOD retrievals are available only in 2008 and 2009 at the UAH site of AERONET. The result of this comparison is discussed in section $3 \mathrm{a}$.

\section{c. Meteorological variables}

As apparent in section 1, correlations between aerosols and lightning, if present, do not necessarily reveal a causal relationship between them. Such correlations could also be related to associations between aerosols and the meteorological conditions that dominate or regulate convection and lightning. In other words, forecasts of the meteorological variables related to such conditions - including updraft strength (Zipser and Lutz 1994), organization of convection (Krehbiel et al. 2000; MacGorman and Rust 1998), and synoptic weather environment (Jacobson and Krider 1976) — may be more 
useful than satellite aerosol retrievals in terms of lightning prediction. Therefore, in addition to the correlation analysis of aerosols and lightning, correlation analyses were performed of meteorological forecasts and lightning. The following meteorological variables were analyzed: forecasts of CAPE that are a measure of the maximum speed of the updraft in the absence of background shear (Emanuel 1994); the vertical wind shear that plays an important role in convection organization (Robe and Emanuel 2001; Rotunno et al. 1988; Weisman and Klemp 1982); and the prevailing wind direction at $850 \mathrm{hPa}$ that indicates the synoptic-scale air mass in the southeastern U.S. summer precipitation regime ( $\mathrm{Li}$ et al. 2012). The vertical wind shear between 850 and $200 \mathrm{hPa}$ is adopted here, for it is one of the noteworthy synoptic features of the warm season heavy rainfall over the interior southeastern United States (Konrad 1997).

Global CAPE fields are derived from the European Centre for Medium-Range Weather Forecasts (ECMWF) ERA-Interim forecast (Dee et al. 2011). We call the derived CAPE fields the CAPE forecast herein. The CAPE forecast is initialized twice a day at 0000 and 1200 UTC. We use the 9-h CAPE forecast field that is initialized at 1200 UTC (0600 LST) so that the CAPE forecast is at 2100 UTC (1500 LST), which falls within the active lightning period-1400-1700 LST. The horizontal resolution of the CAPE forecast is $0.75^{\circ}$. Because the ERAInterim 6-hourly normal wind field data and forecasts are not freely available at $1500 \mathrm{LST}, 3$-hourly $1.25^{\circ}$ wind field reanalysis data were used from the Modern-Era Retrospective Analysis for Research and Applications (MERRA; Rienecker et al. 2011) to calculate the wind shear and wind direction at 1500 LST. The MERRA wind shear data highly agree with the observations at nearest weather stations at 0600 LST (not shown), suggesting the uncertainty introduced by using different sets of forecast-reanalysis data is small.

\section{d. Analysis steps}

The probability distribution of the FR (flashes per minute) during the active lightning period over the study area in Fig. 1 is highly skewed, so a logarithmic transformation (base 10) is applied for a distribution close to normal. The distribution is presented in the results section (section $3 b$ ). The domain-averaged Terra and Aqua AOD retrievals are then matched with later afternoon lightning events during 1400-1700 LST in the 13 summers from 2002 to 2014 for studying the statistical relationship between AOD and the logarithm of flash rate, $\log _{10}(\mathrm{FR})$. Only satellite overpasses with at least 20 MODIS AOD retrievals are kept so that the average AOD is adequately representative over our study area.
In addition, MODIS cannot discern between some thin clouds and aerosols, and the thin clouds are wrongly regarded as aerosols for optical depth retrievals. In other words, some cloudy pixels that show large optical depths are misinterpreted by MODIS as clear-sky pixels with heavy pollution. Therefore, the mean AODs that exceed 1.0 are discarded to remove the potential false heavy pollution cases, although it should be noted that this criterion may also remove some real heavy pollution cases (Van Donkelaar et al. 2011) and cannot remove all the false cases. The cloud influence can be avoided by making use of chemistry models (Stolz et al. 2015, 2017; Storer et al. 2014) to estimate AOD (or CCN concentration). Andreae (2009) suggests a power-law relation between AOD at $500 \mathrm{~nm}$ and $\mathrm{CCN}$ concentration (number $\mathrm{cm}^{-3}$ ) at a supersaturation of $0.4 \%$, where $\mathrm{AOD}=$ $0.0027 \times \mathrm{CCN}^{0.640}$. This empirical relation is adopted here to estimate $\mathrm{CCN}$ concentration using MODIS AOD retrievals. Because $\mathrm{CCN}$ rather than aerosols are the main players in the cloud microphysics that impact the lightning activity (Williams et al. 2002), the results of the analyses in this study are shown in both AOD and $\mathrm{CCN}$ scales. In addition, as previously mentioned, whether aerosols invigorate or suppress deep convection is dependent on meteorological conditions (e.g., Fan et al. 2009; Storer et al. 2010), and hence the usefulness of aerosol information for lightning prediction may vary with environments. The domain-averaged CAPE forecast, wind shear, and wind direction data are matched with afternoon lightning for studying the statistical relationships between these variables and $\log _{10}(\mathrm{FR})$. The cases are further separated into prescribed CAPE forecast and wind shear categories, and then AOD is correlated with $\log _{10}(\mathrm{FR})$ for each category. The results of the correlation analyses are presented in sections $3 \mathrm{~b}$ and $3 \mathrm{c}$.

Because the majority of lightning flashes occur over the deep convective area (DCA; e.g., Holle et al. 1994; Vincent et al. 2004), an association between AOD and increased FR could be due to an enhancement in deep convective area in conditions also favorable for high AOD. The Level 3 composite radar reflectivity data from the Hytop, Alabama $\left(34.927^{\circ} \mathrm{N}, 86.080^{\circ} \mathrm{W}\right)$, KHTX, Next Generation Weather Radar (NEXRAD) System as marked in Fig. 1 are used to define the DCA. The fraction of DCA $\left(F_{\mathrm{DCA}}\right)$ is estimated by calculating the fraction of the study area where the composite radar reflectivity is greater than a threshold $(30,35$, and $40 \mathrm{dBZ})$. The DCA defined as such includes not only the area of the updraft cores but also the area of heavy stratiform precipitation that meets the reflectivity threshold. It is merely a rough estimation of the storm area where lightning is likely to occur, which is similar with the Larsen area (Carey and Rutledge 2000; Larsen and Stansbury 1974). The mean 
$F_{\text {DCA }}$ is calculated by averaging the corresponding values for all the radar scans during the active lightning period. To determine how the FR changes with the DCA, the ratio FR/DCA is calculated by normalizing the FR during radar scans by the DCA. All lightning flashes over the study region within $4 \mathrm{~min}$ after the time of the radar scan are counted. The mean FR/DCA is calculated by averaging the corresponding values for all scans during the active lightning period. The domainaveraged AOD is then correlated with the logarithm (base 10) of the mean fraction of DCA and the logarithm (base 10) of the mean areal FR. The results of the correlation analyses are presented in section $3 \mathrm{e}$.

In addition, in some cases, the detected VHF sources do not look like lightning discharges. These detected sources are often sparsely distributed over the study area where no high composite radar reflectivity area (i.e., DCA) is present. In the correlation analyses of this study, only those cases when a DCA is detected by the radar during the active lightning period are kept. The composite radar reflectivity threshold of $30 \mathrm{dBZ}$ is chosen to filter the storm-related lightning cases. Table 1 documents the sources of all the data used in this study. A flowchart of analysis steps is shown in Fig. 3. The following results section starts with the comparison between MODIS and AERONET AOD retrievals, followed by the correlation analyses of AOD and lightning flashes in different meteorological conditions. Then, the probability of enhanced lightning conditioned on AOD and CAPE forecast is presented. Caveats about the causality of the correlations are discussed last.

\section{Results}

\section{a. Validations of MODIS AOD retrievals}

Satellite AOD retrievals are representative of the aerosol conditions when storms occur only if the change of aerosol particle concentration between the time of the satellite observation and active lightning period is small. The afternoon active lightning period is about 2-4h later than the satellite overpass time. Figure 4 shows mean diurnal variation of AOD at $550 \mathrm{~nm}$ in JJA from 2008 to 2009 at the UAH site of AERONET. At each time, the error bar shows the standard error, which is defined as the ratio of the associated standard deviation to square root of sample number. As observed by the ground-based sun photometer, on average, the daytime variation of AOD over northern Alabama is small, with an amplitude of about 0.03. AOD is maximum during 1000 to 1100 , which corresponds to the Terra overpass period. AERONET AOD is at its minimum from 1400 to 1500 LST, which corresponds to
TABLE 1. Data sources.

\begin{tabular}{ll}
\hline \multicolumn{1}{c}{ Variables } & \multicolumn{1}{c}{ Sources } \\
\hline $\begin{array}{l}\text { Lightning flash } \\
\text { AOD }\end{array}$ & NALMA \\
& $\begin{array}{c}\text { MODIS (Terra and Aqua) Level 2 } \\
\text { Collection 6 }\end{array}$ \\
& AERONET (UAH) Level 2.0 \\
CAPE forecast & ECMWF ERA-Interim \\
Wind shear & MERRA \\
$\begin{array}{l}\text { Composite radar } \\
\text { reflectivity }\end{array}$ & NEXRAD (KHTX) Level 3 \\
\hline
\end{tabular}

the end of the Aqua overpass and beginning of the active lightning period. Therefore, Aqua aerosol retrievals are probably more representative of the aerosol state during the active lightning period. The diurnal variation of aerosol particle (or $\mathrm{CCN}$ ) concentration is largely affected by local and regional weather conditions, including the type of air mass, wind direction, and the formation and dissipation of cumulus clouds upwind of the measuring site (e.g., Jin et al. 2005; Radke and Hobbs 1969; Shen et al. 2011). Increases in CCN concentration often stem from new particle formations (Sihto et al. 2011). The diurnal variation of AOD shown in Fig. 4 resembles those previously reported at Midway Island and Tahiti (Smirnov et al. 2002).

In addition, the uncertainties of the MODIS AOD retrievals need to be small enough so that significant differences in aerosol loadings can be distinguished. Thus, the MODIS AOD retrievals are compared with those at the UAH AERONET site. As shown in Fig. 5, the proportions of samples that fall within the error estimates are $64.3 \%$ and $46.3 \%$ for the Terra and Aqua MODIS retrievals, respectively. The RMSEs of the two are 0.145 and 0.132 , respectively, greater than the previously reported 0.1 (Chu et al. 2002). It appears that the MODIS AOD retrievals are larger than those from AERONET. However, as shown in Fig. 5, the "low" and "high" aerosol loading cases can be distinguished in the AOD retrievals, suggesting the possibility of applying the retrievals for lightning predictions.

\section{b. Statistical relationships}

Figure 6 shows the probability distributions of FR and $\log _{10}$ (FR) during 1400-1700 LST in the JJAs from 2002 to 2014 over northern Alabama. The FR during the active lightning period has a strong variation, ranging seven orders of magnitude. The probability distribution of FR is highly skewed. Many cases have low FRs and a few cases have extraordinarily high FRs. After the logarithmic transformation, the distribution of FR has a more normal distribution. The mean $(M)$ and standard deviation $(\sigma)$ of $\log _{10}(\mathrm{FR})$ are 0.31 and 1.07 , respectively. Figure 7 shows the scatterplots of $\log _{10}(\mathrm{FR})$ and MODIS 


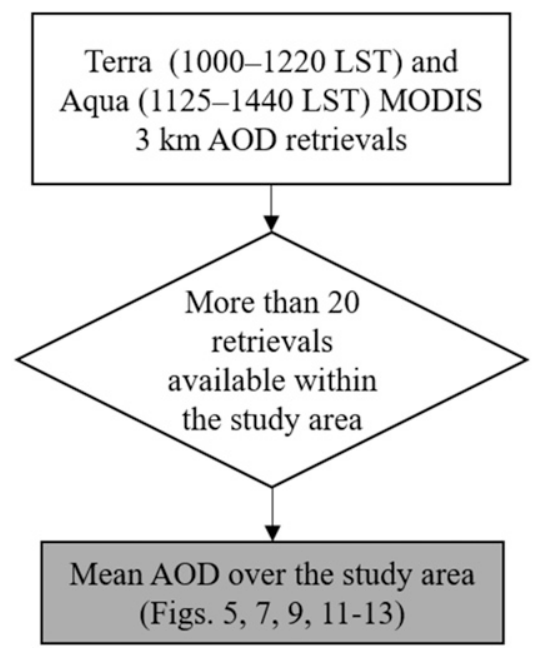

Mean CAPE forecast at 1500 LST over the study area (Figs. 8, 9, 13)

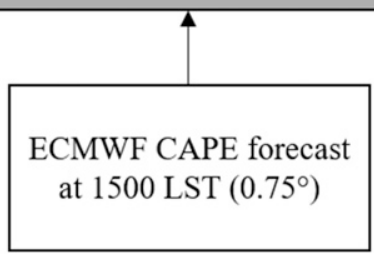

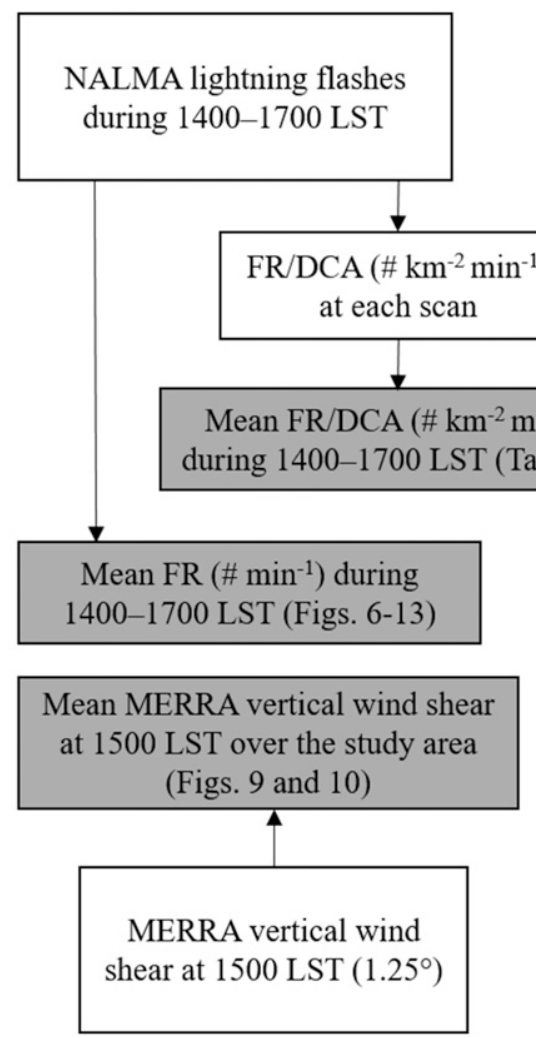

FIG. 3. Flowchart of analysis steps.
NEXRAD Level 3 composite radar reflectivity for all the radar scans during 1400-1700 LST

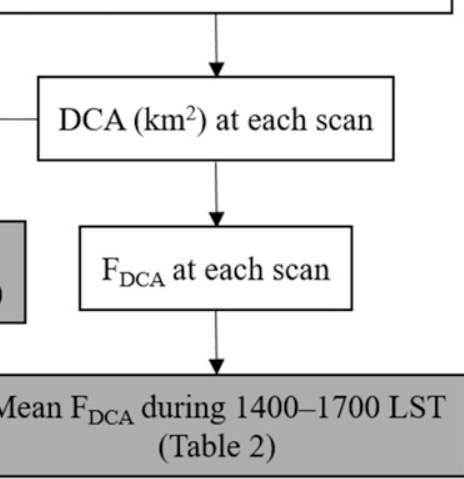

Prevailing wind shear at 1500 LST over the study area (Figs. 10 and 11)

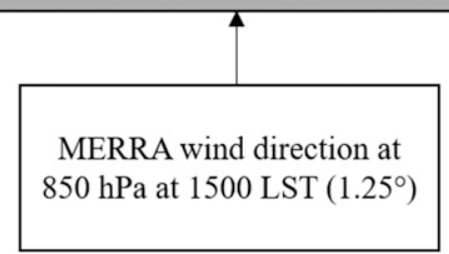

AOD retrievals. It appears that both Terra and Aqua MODIS AOD retrievals are only weakly correlated with $\log _{10}(\mathrm{FR})$ with correlation coefficients of 0.127 and 0.122 , respectively. The apparent weak association between
AOD and $\log _{10}(\mathrm{FR})$ is not necessarily indicative of a causal relationship. Presumably, it is contributed in part by the aerosol invigoration of convection as suggested by previous studies (e.g., Williams et al. 2002). However,

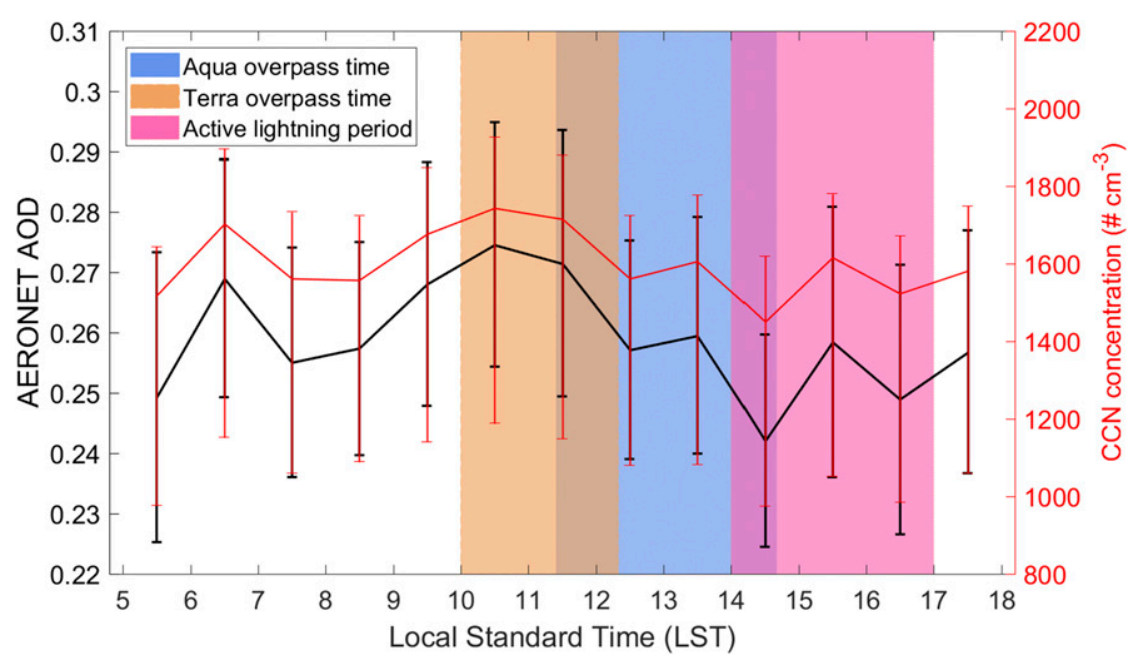

FIG. 4. Mean diurnal variation of AOD at $550 \mathrm{~nm}$ (black curve; left $y$ axis) and associated CCN concentration estimation (Andreae 2009; red curve; right $y$ axis) in JJA from 2008 to 2009 at the UAH site of AERONET. The error bars show the standard errors. The brown-, blue-, and pink-shaded areas correspond to the Terra overpass time interval, the Aqua overpass time interval, and the active lightning period (1400-1700 LST), respectively. 

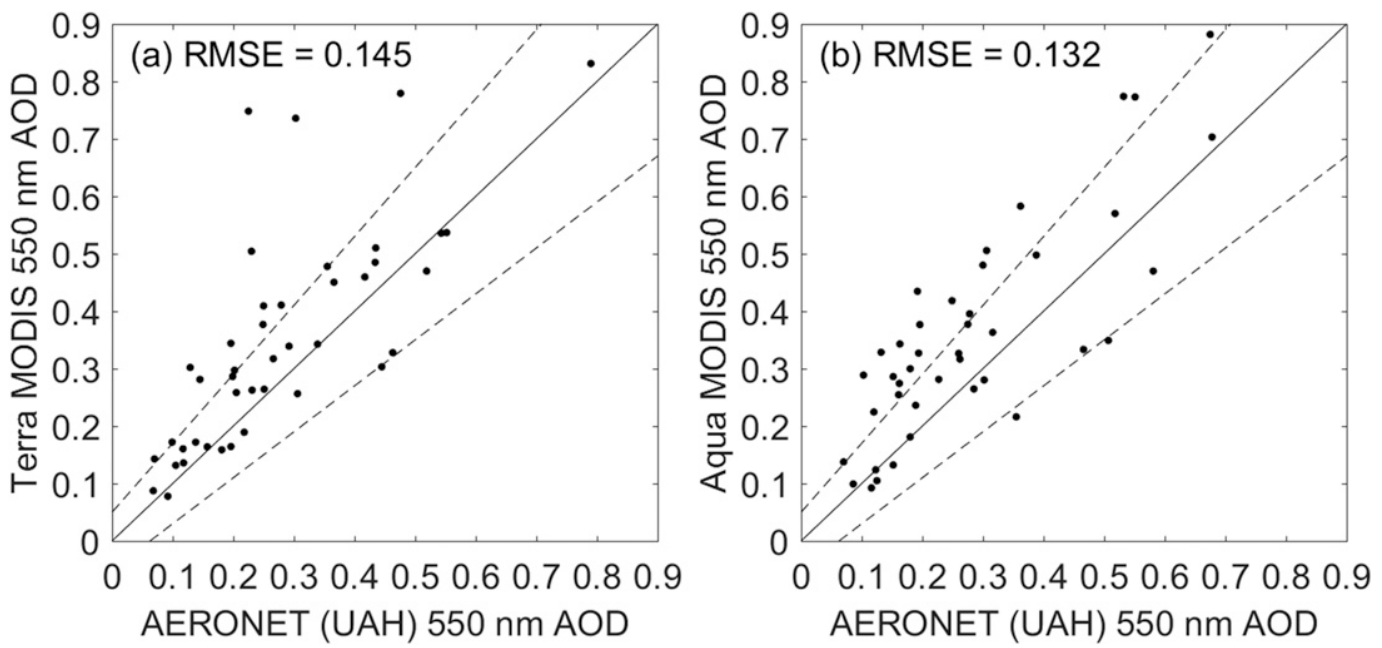

FIG. 5. Scatterplots of MODIS and AERONET AOD retrievals at $550 \mathrm{~nm}$ in the JJAs from 2008 to 2009 for (a) Terra and (b) Aqua MODIS. In (a) and (b), the two dashed lines mark the previously reported MODIS AOD uncertainties $\pm 0.05 \pm 0.20 \times$ AOD (Chu et al. 2002). Each MODIS AOD is the average over a circle centered on the UAH site with a radius of $50 \mathrm{~km}$. Each AERONET AOD is the average $0.5 \mathrm{~h}$ before and after the satellite overpass time.

because precipitation scavenging is a highly efficient removal mechanism of water-soluble aerosol particles (Atlas and Giam 1988; Hales and Dana 1979), we speculate that the concentration of air pollution may gradually increase in consecutive nonrainy days and produce a high value right before being washed out. Moreover, the polluted environment might tend to be associated with particular meteorological conditions that occasionally lead to enhanced
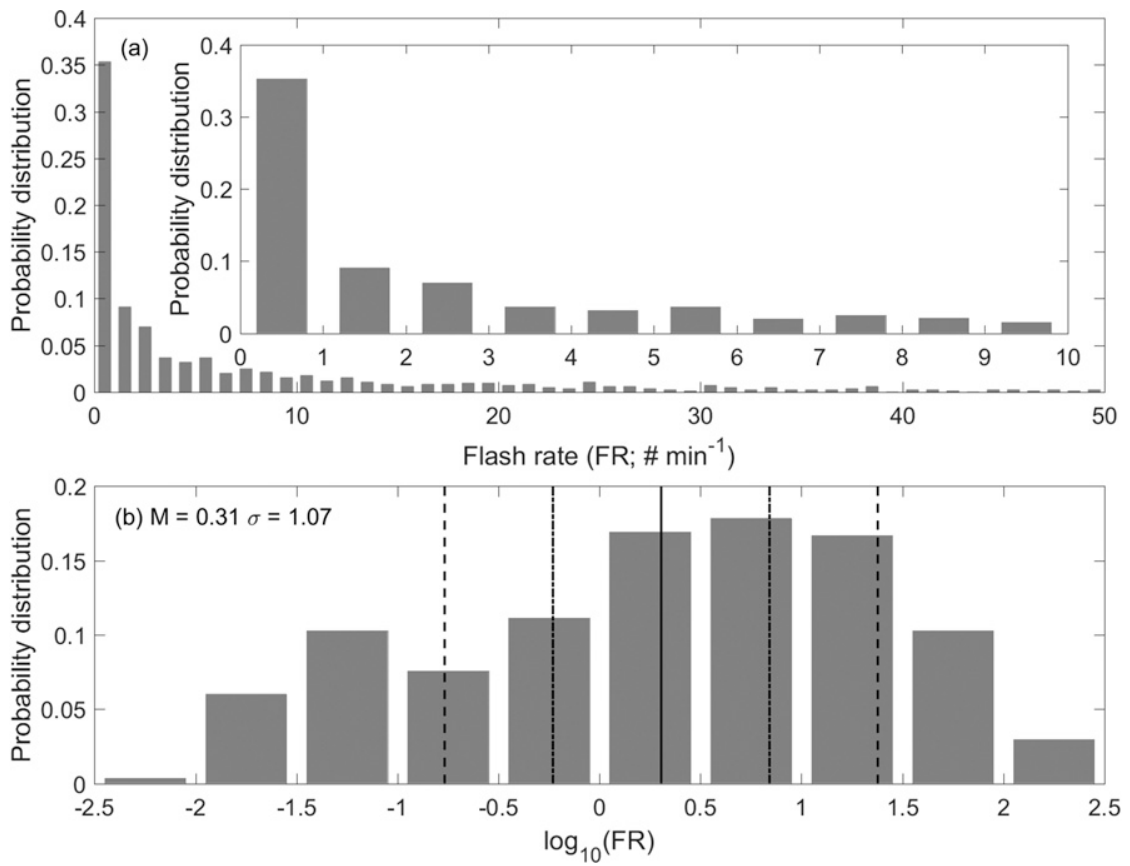

FIG. 6. The probability distributions of (a) FR (number per minute) and (b) the logarithm of flash rate during 1400-1700 LST in the JJAs from 2002 to 2014 over northern Alabama. The inset of (a) is a close-up of the samples with a flash rate $<10$ flashes per minute. The $M$ and $\sigma$ are the mean and standard deviation of the logarithm of flash rate, respectively. In (b), the solid back vertical line denotes the mean; the two dashed vertical lines denote $M \pm \sigma$, respectively; and the two dot-dashed vertical lines denote $M \pm \sigma / 2$, respectively. 

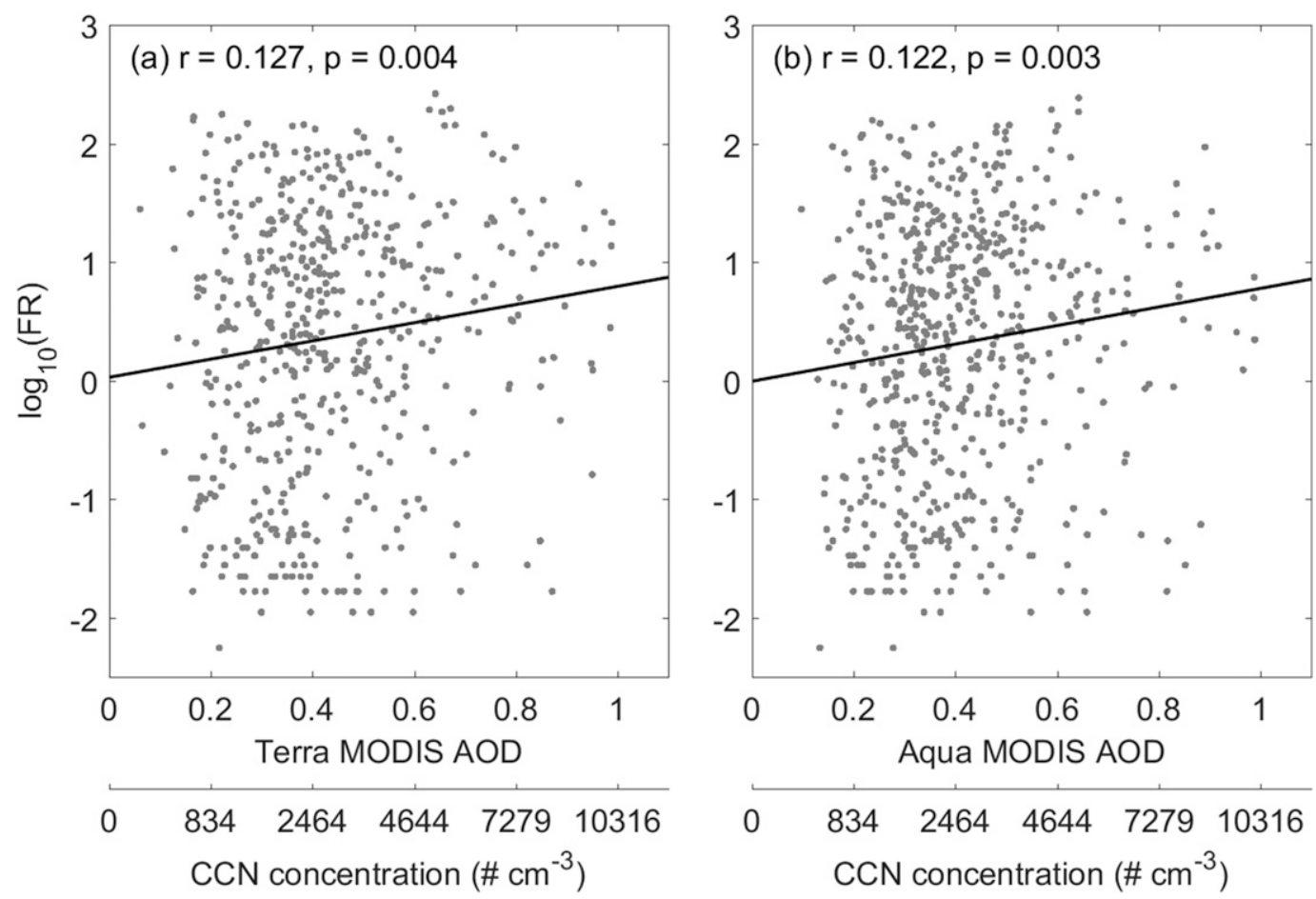

FIG. 7. Scatterplots of the logarithm of flash rate and the mean MODIS AOD with associated CCN scales using Andreae (2009). (a) Terra and (b) Aqua. The solid line is the linear regression; $r$ is the correlation coefficient, and $p$ is the $p$ value of the $t$ test.

lightning. These hypothetical linkages could also lead to the weak positive correlation between AOD and $\log _{10}(\mathrm{FR})$. Some of the noise in the relationship can be smoothed out if the data are binned into discrete intervals (Stolz et al. 2017), but the strength of the positive correlation depends on the number of bins selected (not shown).

\section{c. Correlations in different meteorological conditions}

Previous studies (e.g., Morales Rodriguez et al. 2010; Williams et al. 2002) have suggested that meteorological conditions may be more important than aerosols in regulating convection and lightning. Figures $8 \mathrm{a}$ and $8 \mathrm{~b}$ show the scatterplots of the $\log _{10}(\mathrm{FR})$ and the square root of CAPE $\left(\mathrm{CAPE}^{1 / 2}\right)$ forecast and the $\log _{10}(\mathrm{FR})$ and the wind shear, respectively. The $\mathrm{CAPE}^{1 / 2}$, an indicator of the maximum updraft without background shear, has a moderate correlation with the $\log _{10}(\mathrm{FR})$, stronger than those between the MODIS AOD and the $\log _{10}(\mathrm{FR})$. The correlation coefficient is 0.530 . These results agree with the previous studies (e.g., Williams et al. 2002; Zipser and Lutz 1994), which underscores the remarkable role the strong updraft plays in determining the lightning FR.

Increasing the vertical wind shear above the boundary layer generally leads to stronger organized convection
(Robe and Emanuel 2001) and hence more flashes. By contrast, the wind shear shows a weak negative correlation with $\log _{10}(\mathrm{FR})$ with a correlation coefficient of -0.248 . The negative correlation between the wind shear and $\log _{10}(\mathrm{FR})$ in this study may be explained by the negative association between the wind shear and the CAPE (not shown). In the summer when solar heating and CAPE tend to be strongest, the upper jet stream is often located north of Alabama, leading to decreased deep-layer vertical wind shear yet adequate instability for thunderstorms that could still have a high FR. In the mesoscale convective complex, the deep-layer vertical wind shear can be weakened as convection intensifies via the vertical momentum transport (Wu and Yanai 1994).

The correlations between the MODIS AOD retrievals and $\log _{10}($ FR) are weak (Fig. 7). However, as previously mentioned, whether aerosols enhance or suppress convection is dependent upon CAPE and wind shear (Fan et al. 2009; Storer et al. 2010). Therefore, the correlation between aerosols and FR, and hence the usefulness of the MODIS AOD retrievals in predicting lightning, may vary with meteorological conditions. Figure 9 shows the correlation coefficients between the mean MODIS AOD and the $\log _{10}(\mathrm{FR})$ in different wind shear and CAPE forecast groups. 

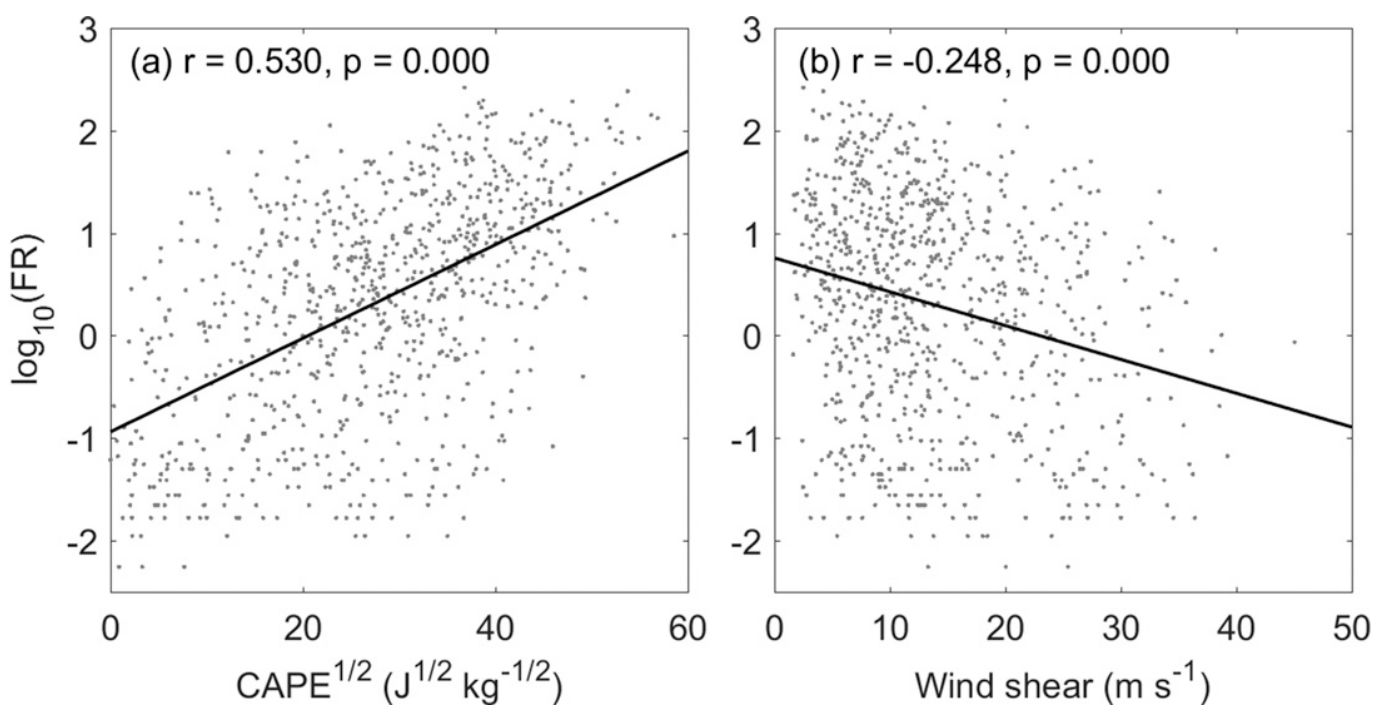

FIG. 8. Scatterplots of the (a) logarithm of flash rate and the square root of CAPE forecast and (b) logarithm of flash rate and the wind shear. The solid line is the linear regression; $r$ is the correlation coefficient, and $p$ is the $p$ value of the $t$ test.

The strongest correlation between the MODIS AOD and the $\log _{10}(\mathrm{FR})$ is present when wind shear is weak (Fig. 9), in agreement with Fan et al. (2009). The correlation appears to be strongest and most significant if the forecast CAPE is low and the wind shear is weak. As a result, the MODIS AOD-based enhanced lightning tendency information might be more useful in terms of forecast metrics, if a weak wind shear and/or low CAPE environment is forecast. However, the forecasts of variables CAPE and wind shear still have stronger correlations with lightning FR (Fig. 8).
Figures 10a and 10b show the boxplot of $\log _{10}(\mathrm{FR})$ in different wind direction regimes and the corresponding sample proportions, respectively. The prevailing wind observations are grouped into one of the eight directionsnorth $(\mathrm{N})$, northeast (NE), east (E), southeast (SE), south (S), southwest (SW), west (W), and northwest (NW)over the study area using the MERRA $850-\mathrm{hPa}$ wind data. It appears that $\log _{10}(\mathrm{FR})$ is somewhat dependent upon prevailing wind directions. A large portion of lightning cases are associated with days with prevailing westerly winds (Fig. 10), and such lightning events appear to be

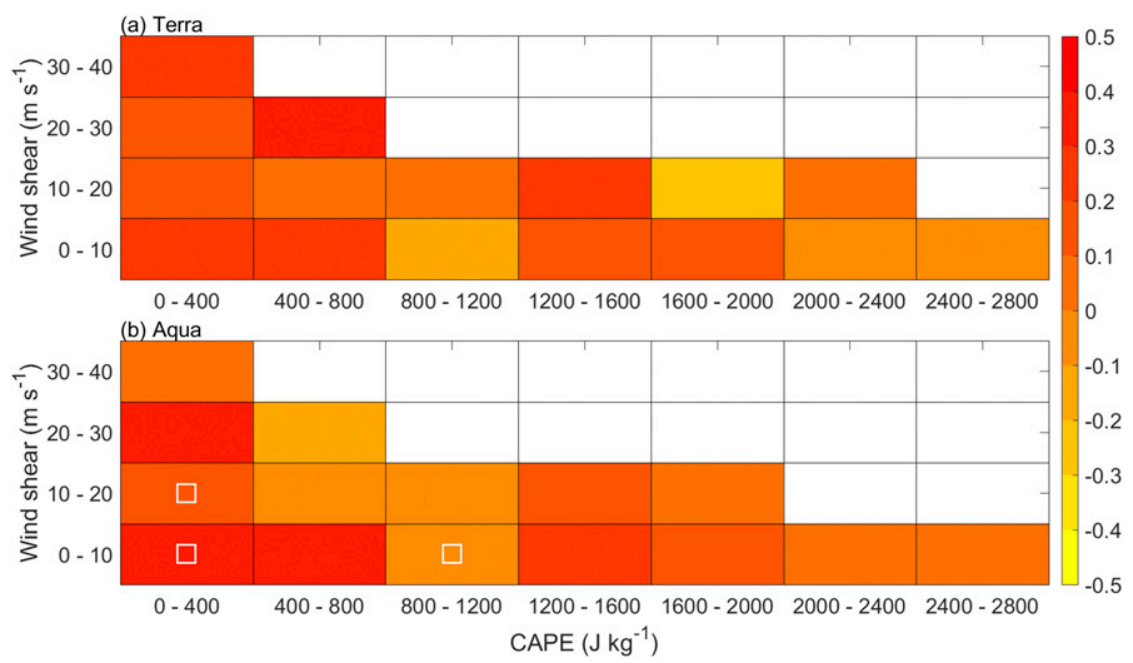

FIG. 9. Correlation coefficients between the MODIS AOD and the $\log _{10}(\mathrm{FR})$ in different wind shear and CAPE forecast categories for the (a) Terra and (b) Aqua cases. White squares denote the correlations that pass the $t$ test at a significance level of 0.05 . 

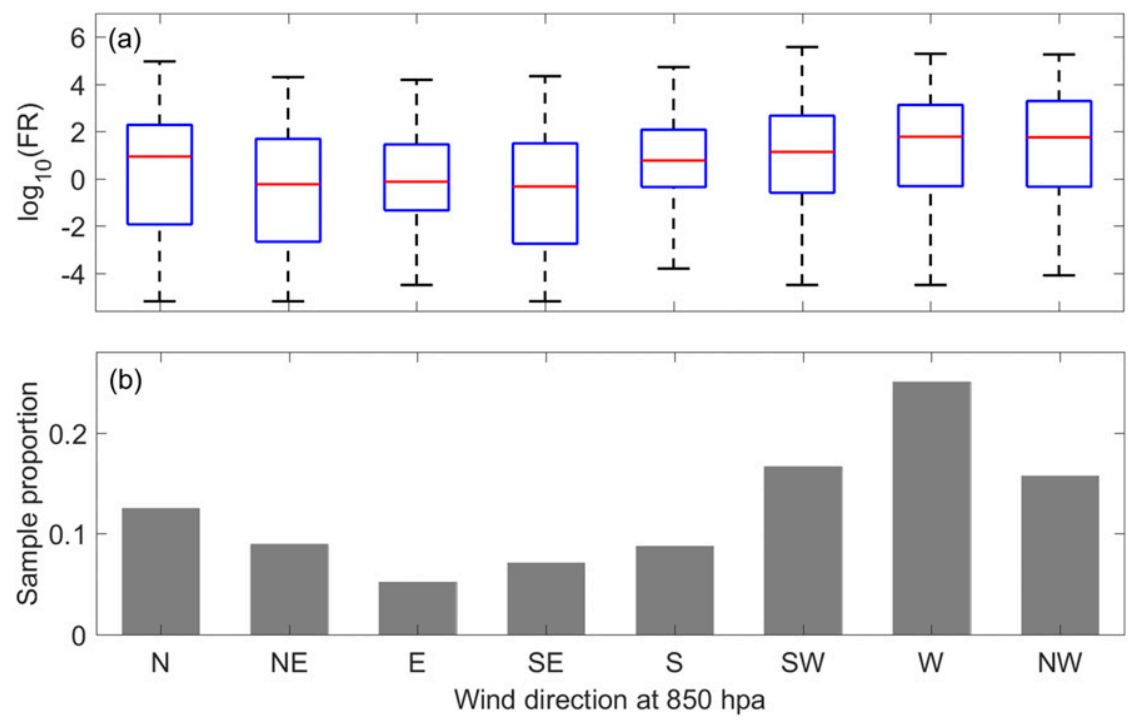

FIG. 10. (a) Boxplot of the logarithm of flash rate in different wind direction regimes, and (b) the corresponding sample proportions. On each blue box in (a), the central red line is the median, and the bottom and top edges of the box are the 25 th and 75 th percentiles, respectively. The whiskers extend to the most extreme data points excluding the outliers.

stronger than those associated with easterlies in terms of the median of $\log _{10}(\mathrm{FR})$ (Fig. 10), suggesting that wind directions may be indicative of air mass and intensification of convection. The storms with relatively higher FRs over the study area from the west may be associated with baroclinicity, or cases of baroclinic Rossby-type short waves, while the storms with relatively low FRs from the east may be local thermally driven thunderstorms. A comparison of Figs. 7, 8, and 10 suggests that aerosols are less important than thermodynamics in shaping the FR in a convective system. Forecasts of other meteorological variables that are more closely linked to the intensification of convection, such as $\mathrm{CAPE}^{1 / 2}$, are without doubt more useful than satellite AOD retrievals in lightning inferences.

Figure 11 shows the correlation coefficients between AOD and $\log _{10}(\mathrm{FR})$ in the 8 wind direction regimes. The correlation is stronger and more significant when northerlies prevail than when southerlies prevail over
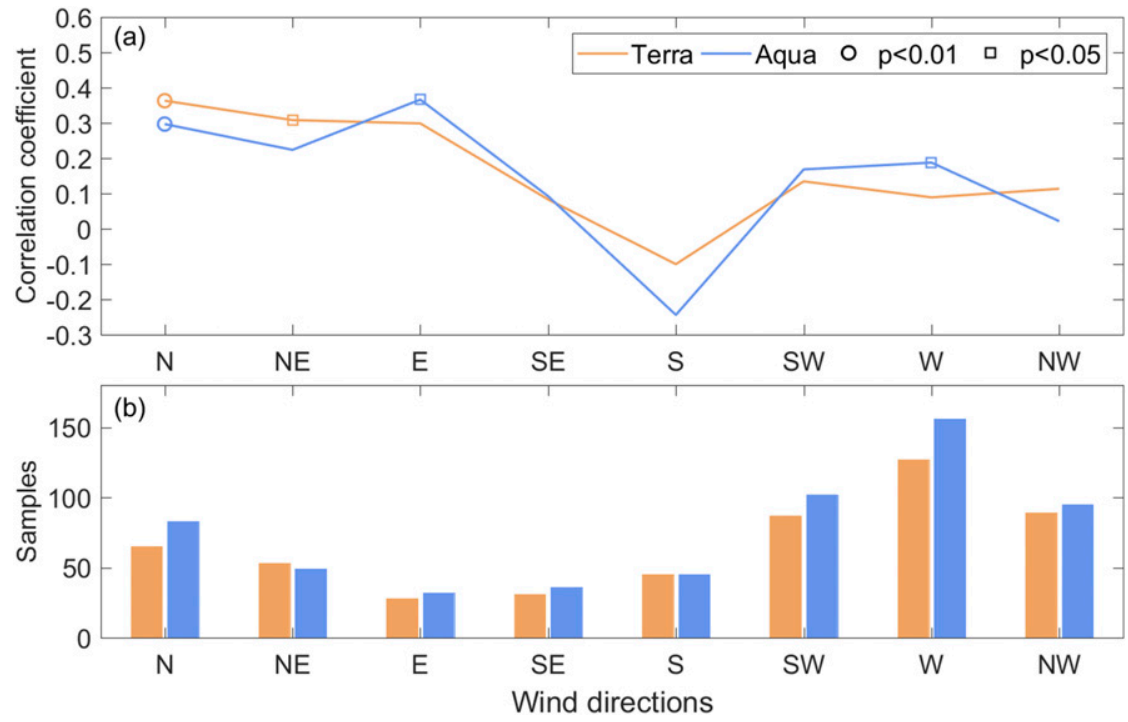

FIG. 11. (a) Correlation coefficients between AOD and $\log _{10}(\mathrm{FR})$ in the eight wind direction regimes, and (b) the corresponding samples. In (a), the correlations that pass the $t$ test with significance levels of 0.01 and 0.05 are marked by circles and squares, respectively. 
the study area, suggesting that aerosols might have a greater impact on the FRs for the thunderstorms that move from north to south than those that move from south to north. Over northern Alabama, northerly winds tend to bring with them more polluted continental air masses that have resided over the United States for several days at least, with aerosol source regions in the Midwest, Ohio Valley, and northeastern United States. In contrast, southerly winds are associated with more pristine air masses from the Gulf of Mexico, although smoke pollution scenarios occasionally happen when central American biomass burning is active (Saide et al. 2015). These results support, in the presence of northerly winds, the increased correlation between aerosols and lightning flashes contributed by the impacts of land-based aerosols on increased lightning FRs.

\section{d. Conditional probability of enhanced lightning}

In spite of the weak correlations between the MODIS AOD retrievals and $\log _{10}(\mathrm{FR})$, such AOD retrievals may be useful in inferences of lightning activity in combination with the forecasts of other meteorological variables. Here, we use the MODIS AOD retrievals and the forecasts of $\mathrm{CAPE}^{1 / 2}$ for an illustration. A half standard deviation $(\sigma)$ above the mean $(M)$ is used as a threshold to separate the enhanced lightning $\left[\log _{10}(\mathrm{FR})>M+\sigma / 2\right]$ from the less active lightning cases $\left[\log _{10}(\mathrm{FR})<M-\sigma / 2\right]$, and then the conditional probability of enhanced lightning events is discussed. The subjective choice of the $M \pm \sigma / 2$ thresholds has also been adopted by previous meteorological and climatological studies, such as the classification of the $\mathrm{El}$ Niño-Southern Oscillation (ENSO) events (Phillips et al. 1998; Ropelewski and Halpert 1996).

First, if the AOD is the only available predictor of enhanced lightning, an AOD threshold $\left(\mathrm{AOD}_{0}\right)$ is selected to maximize the conditional probability of enhanced lightning given that $\mathrm{AOD}>\mathrm{AOD}_{0}$ occurs, that is, maximizing Prob $\left[\log _{10}(\mathrm{FR})>M+\sigma / 2\right.$ for AOD $>$ $\left.\mathrm{AOD}_{0}\right]$. Figure 12 shows the conditions when the maximum probabilities of enhanced lightning conditioned on the MODIS AOD-based inference are reached. This probability maximizes when $\mathrm{AOD}_{0}=0.40$ using the Terra MODIS AOD retrievals, and it maximizes when $\mathrm{AOD}_{0}=0.44$ using the Aqua MODIS AOD retrievals. Such an enhanced lightning inference minimizes the false alarm ratio (FAR), since FAR $=1-$ $\operatorname{Prob}\left[\log _{10}(\mathrm{FR})>M+\sigma / 2\right.$ for $\left.\mathrm{AOD}>\mathrm{AOD}_{0}\right]$. As shown in Fig. 12, the FAR of an enhanced lightning inference decreases from 178/268 (66.4\%) when the Terra AOD $\leq 0.40$ to $138 / 257$ (53.7\%) when the Terra AOD > 0.40; it decreases from $258 / 380(67.9 \%)$ when the Aqua AOD $\leq 0.44$ to $122 / 218(56.0 \%)$ when the Aqua AOD $>$

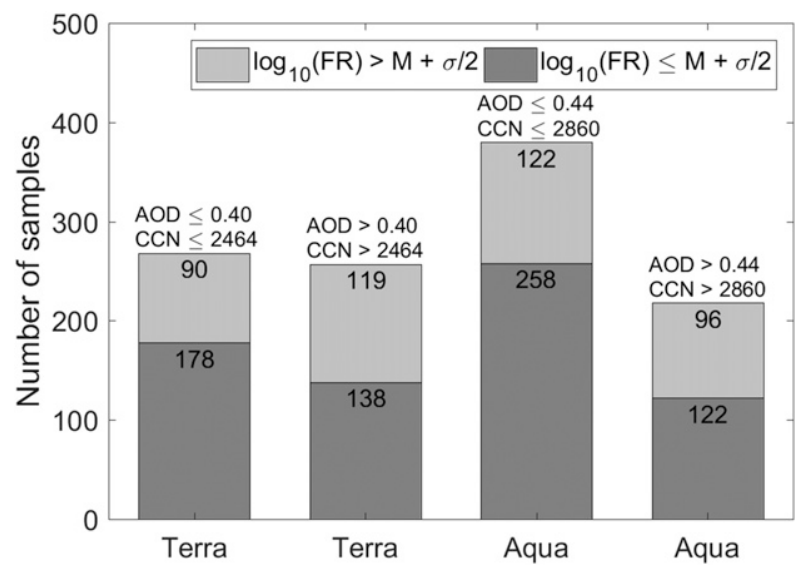

FIG. 12. Conditions when the maximum conditional probabilities of enhanced lightning are reached given that $\mathrm{AOD}>\mathrm{AOD}_{0}$ (or $\mathrm{CCN}>\mathrm{CCN}_{0}$; Andreae 2009), $\operatorname{Prob}\left[\log _{10}(\mathrm{FR})>M+\sigma / 2\right.$ for $\left.\mathrm{AOD}>\mathrm{AOD}_{0}\right]\left.\right|_{\max }$.

0.44 . Hence, if the AOD is the only accessible variable for enhanced lightning prediction, then at best only about half of such inferences will be correct.

If the CAPE forecast is also available, the two variables can be used together for enhanced lightning inference. In a similar way, the AOD and CAPE forecast thresholds are selected to maximize the conditional probability of enhanced lightning given that both $\mathrm{AOD}>\mathrm{AOD}_{0}$ and $\mathrm{CAPE}^{1 / 2}>\mathrm{CAPE}_{0}^{1 / 2}$ occur. Figure 13 shows the occurrence probability of enhanced lightning conditioned on using both the CAPE forecasts and the MODIS AOD retrievals, $\operatorname{Prob}\left[\log _{10}(\mathrm{FR})>M+\sigma / 2\right.$ for $\mathrm{AOD}>\mathrm{AOD}_{0}$, $\left.\mathrm{CAPE}^{1 / 2}>\mathrm{CAPE}_{0}^{1 / 2}\right]$, that is, the likeliness of a successful inference of an enhanced lightning event for any pair of arbitrarily selected $\mathrm{AOD}_{0}$ and $\mathrm{CAPE}_{0}$. The higher the threshold of the predictor $\left(\mathrm{AOD}_{0}\right.$ or $\left.\mathrm{CAPE}_{0}^{1 / 2}\right)$ is, the lower the FAR is. Notwithstanding the secondary role aerosols play in shaping lightning activity compared to the CAPE (Figs. 7 and 8), an enhanced lightning predictor that includes AOD can have a lower FAR than that based only on $\mathrm{CAPE}^{1 / 2}$, when a relatively low $\mathrm{CAPE}^{1 / 2}$ is forecast (Fig. 13). It should be noted that the samples included in the conditional probability analyses (Figs. 12 and 13) are all the cases where lightning flashes were detected by the NALMA; the cases with no detected lightning flashes are not included.

As shown in Fig. 13, enhanced lightning will always happen if the forecast CAPE ${ }^{1 / 2}$ is greater than $50 \mathrm{~J}^{1 / 2} \mathrm{~kg}^{-1 / 2}$ for lightning-producing storms. In such a situation, the conditional probability of enhanced lightning is not affected if the aerosol state is known. However, if weaker CAPE is predicted, then the awareness of aerosol state may increase the conditional probability of enhanced lightning. When the Terra AOD is greater than 0.90, 


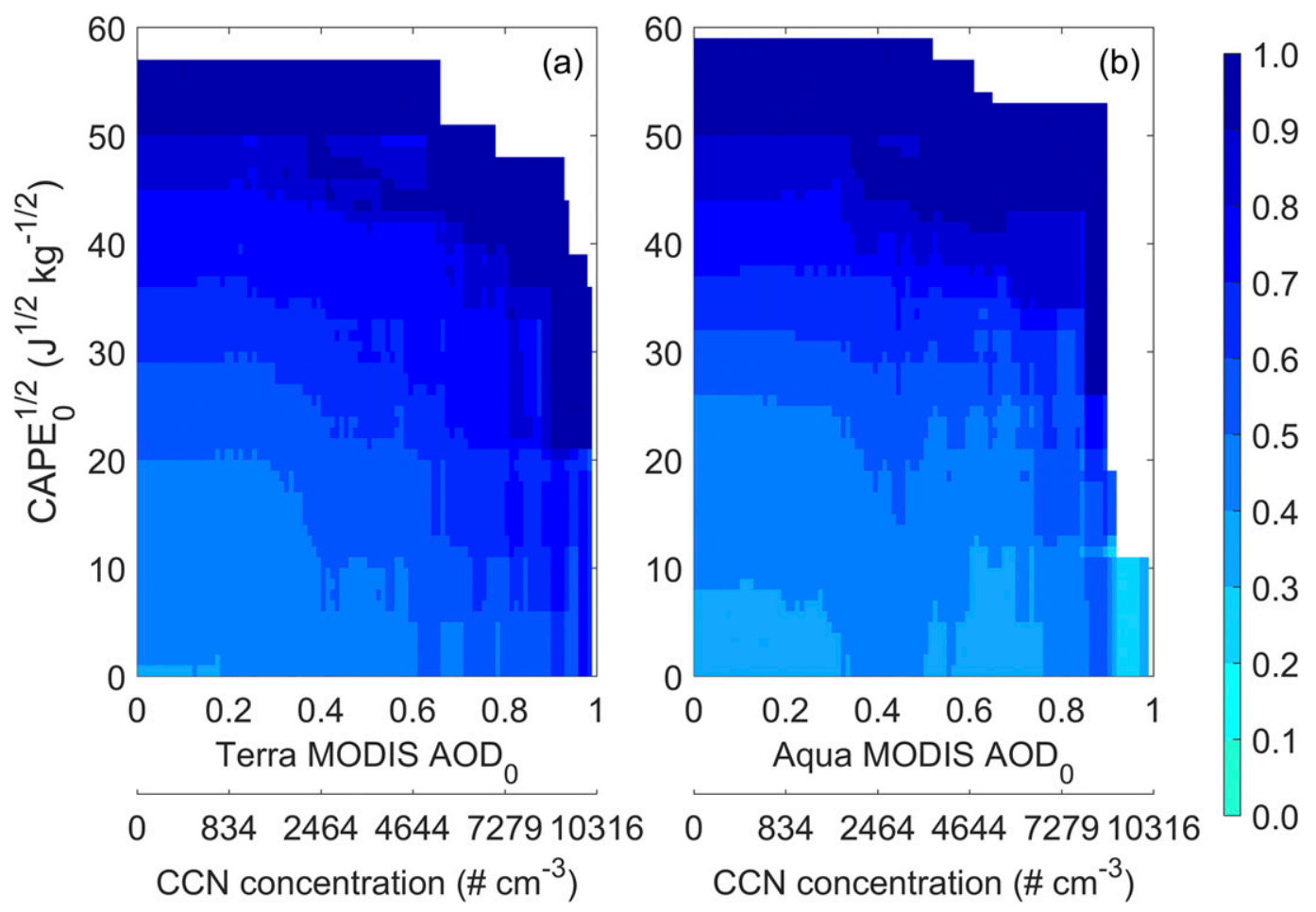

FIG. 13. The occurrence probability of enhanced lightning conditioned on the inference using both the square roots of CAPE forecasts and the AOD retrievals from the (a) Terra MODIS or (b) Aqua MODIS, with associated $\mathrm{CCN}$ scales using Andreae (2009), $\operatorname{Prob}\left[\log _{10}(\mathrm{FR})>M+\sigma / 2\right.$ for $\left.\mathrm{AOD}>\mathrm{AOD}_{0}, \mathrm{CAPE}^{1 / 2}>\mathrm{CAPE}_{0}^{1 / 2}\right]$.

enhanced lightning will most likely occur if the $\mathrm{CAPE}^{1 / 2}$ forecast is greater than $22 \mathrm{~J}^{1 / 2} \mathrm{~kg}^{-1 / 2}$; when the Aqua AOD is greater than 0.85 , enhanced lightning will most likely occur if the $\mathrm{CAPE}^{1 / 2}$ forecast is greater than $29 \mathrm{~J}^{1 / 2} \mathrm{~kg}^{-1 / 2}$ (Fig. 13). The results suggest that a polluted environment seems more favorable for enhanced lightning than a clean environment, if the CAPE forecast is not large. The results shown in Fig. 13 resemble the one in the shallow warm cloud depth (between 2.0 and $3.5 \mathrm{~km}$ ) regime over continents reported by Stolz et al. (2015) using CCN concentration and normalized CAPE.

\section{e. Deep convective area and flash rate per unit deep convective area}

The association between a polluted environment and increased FR may result from the linkage between aerosols and the area covered by deep convection or the linkage between aerosols and the number of flashes per storm area. The aerosol-lightning enhancement may be caused by enhanced updraft strength of convective cores or more widespread storm area, of which the underlying mechanisms may not be the same. Table 2 documents the correlation coefficients between AOD and $\log _{10}\left(F_{\mathrm{DCA}}\right)$ and the correlation coefficients between AOD and $\log _{10}(\mathrm{FR} / \mathrm{DCA})$. AOD and $\log _{10}\left(F_{\mathrm{DCA}}\right)$ show weak correlations, which are not sensitive to the radar reflectivity thresholds used to define the DCA (Table 2). The correlation coefficient between the Aqua MODIS AOD and the $\log _{10}\left(F_{\mathrm{DCA}}\right)$ is slightly higher than that between of the Terra MODIS AOD. The correlations are greater than their AOD and $\log _{10}(\mathrm{FR})$ counterparts (Fig. 7 and Table 2). This suggests that the areal coverage of deep convection

TABLE 2. Correlation coefficients between AOD and $\log _{10}\left(F_{\mathrm{DCA}}\right)$ and correlation coefficients between AOD and $\log _{10}(\mathrm{FR} / \mathrm{DCA})$. Asterisks specify significance levels: * indicates $t$-test statistics at a significance level of $0.05 ; *$ indicates $t$-test statistics at a significance level of 0.01 .

\begin{tabular}{|c|c|c|c|c|}
\hline \multirow[b]{2}{*}{ DCA definition } & \multicolumn{2}{|c|}{ Terra MODIS AOD } & \multicolumn{2}{|c|}{ Aqua MODIS AOD } \\
\hline & vs $\log _{10}\left(F_{\mathrm{DCA}}\right)$ & vs $\log _{10}(\mathrm{FR} / \mathrm{DCA})$ & vs $\log _{10}\left(F_{\mathrm{DCA}}\right)$ & vs $\log _{10}(\mathrm{FR} / \mathrm{DCA})$ \\
\hline$\geq 30 \mathrm{~dB} Z$ & $0.200^{* *}$ & $-0.106^{*}$ & $0.216^{* *}$ & $-0.122 * *$ \\
\hline$\geq 35 \mathrm{dBZ}$ & $0.168^{* *}$ & $-0.105^{*}$ & $0.186^{* *}$ & $-0.112 * *$ \\
\hline$\geq 40 \mathrm{~dB} Z$ & $0.177 * *$ & $-0.097 *$ & $0.183 * *$ & $-0.113^{* *}$ \\
\hline
\end{tabular}


also increases with an increase in AOD; however, whether this is linked to aerosol state or other coincident meteorological conditions is unknown. In fact, the thermodynamic quantity CAPE and the aerosol AOD are not independent variables. The square root of CAPE forecast has correlation coefficients of 0.326 and 0.277 with Terra and Aqua MODIS AOD retrievals, respectively (not shown).

On the contrary, AOD and $\log _{10}(\mathrm{FR} / \mathrm{DCA})$ show weak negative correlations, which are also not sensitive to the definitions of DCA (Table 2). As a consequence, not only are polluted environments associated with an increased DCA, but they are also associated with a decreased FR per storm area. However, we have not analyzed the storm characteristics that make up this distribution. The positive dependence between AOD and $\log _{10}\left(F_{\mathrm{DCA}}\right)$ supports previous modeling studies, which suggest that clouds arising in a polluted environment produce stronger downdrafts and gust fronts, and stronger secondary convection (Khain et al. 2005; Lee and Feingold 2010). We speculate that the aerosol enhancement of lightning, if present, may be associated with enhanced convergence in the boundary layer and secondary convection.

\section{Discussion and conclusions}

Among currently available satellite aerosol retrievals, MODIS aerosol retrievals were explored here for their utility in improving lightning nowcasts. The long-term mean lightning activity peaks in the late afternoon over northern Alabama, consistent with worldwide activity (Blakeslee et al. 2014; Williams and Heckman 1993), including the three major components of the global electrical circuit-Africa, South America, and the Maritime Continent (Williams and Satori 2004). In the daytime, the Terra and Aqua satellites pass the area near noon and in the early afternoon local time, respectively, about $2-4 \mathrm{~h}$ earlier than the peak lightning activity period. In addition, the AERONET ground-based sun photometer measurements show that the difference between the mean aerosol loadings near the satellite overpass time and the active lightning period is less than $3 \%$. Moreover, the uncertainties of MODIS AOD retrievals are low (RMSE <0.15). Hence, Terra and Aqua MODIS AOD retrievals may be close to the aerosol loading state during the active lightning period, and thus have the potential for improving lightning predictions.

The lightning FR and MODIS AOD retrievals show weak positive correlations, smaller than those between FR and the forecasts of meteorological variables that are crucial to the intensification of convection. Consequently, MODIS AOD retrievals are less useful than such meteorological forecasts in lightning prediction.
Correlations between FR and AOD retrievals become stronger and more significant if a weak wind shear and/ or a low CAPE environment are forecasted. They are stronger and more significant when northerly winds prevail than when southerly winds prevail. For the storms where a CAPE forecast is available, an enhanced lightning predictor that includes AOD may have a lower FAR than that based only on CAPE forecast. When an adequately strong CAPE is forecasted, enhanced lightning will always occur irrespective of the aerosol state. However, when relatively weaker CAPE is forecasted, enhanced lightning is more likely to occur in a polluted environment than in a clean environment.

The correlation between aerosols and FR does not necessarily suggest that aerosols impact deep convection. The association between aerosols and the DCA may contribute to the correlations. However, it does not appear that increased AOD is associated with increased flashes per storm area. Our findings show a weak negative correlation between aerosols and the flashes per storm area. We speculate that the aerosol enhancement of lightning, if present, may be associated with enhanced convergence in the boundary layer and secondary convection (Khain et al. 2005; Lee and Feingold 2010). Stronger correlations are present between aerosols and flashes (or DCAs) in particular meteorological conditions such as weak vertical wind shear and prevailing northerly winds. The results suggest that knowledge of aerosols may improve lightning forecasts with aerosol sensitive microphysics schemes in the context of lightning rate parameterizations (e.g., Fierro et al. 2013).

If the aerosol microphysics effect (Williams et al. 2002) is the main link between aerosols and lightning activity, then the correlations between aerosol and lightning flash rate would be stronger if $\mathrm{CCN}$ were the measured quantity rather than AOD. The MODIS aerosol algorithm has been adapted to the Visible Infrared Imaging Radiometer Suite (VIIRS) instrument on board the Suomi National Polar-Orbiting Partnership $(S N P P)$ satellite, which was launched more recently in October 2011 (Jackson et al. 2013). The VIIRS aerosol retrievals may be used as part of a real-time lightning prediction component in a similar way after the Terra and Aqua satellites are retired.

This study focuses on the diurnally most active lightning period, 2-4h later than the Terra and Aqua overpass times. However, lightning also occurs at other times. Whether or not satellite aerosol retrievals are capable of improving the prediction of lightning that occurs after a longer period-such as the nighttime or the next morning-remains unknown. The Geostationary Operational Environmental Satellite R (GOES-R) series will provide AOD retrievals 12 times per hour 
over the contiguous United States (CONUS) during the daytime using Advanced Baseline Imager (ABI) observations. GOES-R (GOES-16 and beyond) aerosol retrievals may have greater potential than MODIS for improving the predictions of lightning outside the most active lightning period. The aerosol invigoration of convection sometimes occurs in the downwind area from the aerosol source (e.g., Fan et al. 2015; Wang et al. 2014). The usefulness of the information about aerosol upwind of deep convection and the types of aerosols (Proestakis et al. 2016b) in improving lightning forecast has not been discussed in this study and may be important in regions with large anthropogenic aerosol variability.

Acknowledgments. We thank Dr. Kevin Knupp for his effort in establishing and maintaining the UAH site of AERONET. We thank Dr. Lawrence Carey, Dr. Xuanli Li, Dr. Christopher Nowotarski, Dr. Derek Posselt, and Dr. Huiyan Sang for their instructive suggestions and comments for this work. We thank Dr. Rachel Albrecht, Dr. Barry Lynn, Dr. Earle Williams, and another anonymous reviewer for their helpful comments for this paper. We also thank the Texas A\&M High Performance Research Computing for providing the disk quota and software for processing the data in this work. The contributions of T. Ren, A. D. Rapp, and S. L. Nasiri were supported by NSF Grant AGS-1261392 at Texas A\&M University; J. R. Mecikalski and J. Apke's contributions were supported by NSF Grant AGS-1261368. The NALMA data were acquired from the Global Hydrology Resource Center (GHRC) Distributed Active Archive Center (DAAC), located in the National Space Science and Technology Center (NSSTC) in Huntsville, Alabama (https://ghrc.nsstc.nasa.gov/). The Terra and Aqua MODIS Aerosol 5-Min L2 Swath $3 \mathrm{~km}$ V006 datasets were acquired from the Level-1 and Atmosphere Archive and Distribution System (LAADS) DAAC, located in the Goddard Space Flight Center (GSFC) in Greenbelt, Maryland (https:// ladsweb.nascom.nasa.gov/).

\section{REFERENCES}

Albrecht, B. A., 1989: Aerosols, cloud microphysics, and fractional cloudiness. Science, 245, 1227-1230, https://doi.org/10.1126/ science.245.4923.1227.

Albrecht, R. I., C. A. Morales, and M. A. Silva Dias, 2011: Electrification of precipitating systems over the Amazon: Physical processes of thunderstorm development. J. Geophys. Res., 116, D08209, https://doi.org/10.1029/2010JD014756.

, S. J. Goodman, D. E. Buechler, R. J. Blakeslee, and H. J. Christian, 2016: Where are the lightning hotspots on Earth? Bull. Amer. Meteor. Soc., 97, 2051-2068, https://doi.org/ 10.1175/BAMS-D-14-00193.1.
Altaratz, O., I. Koren, Y. Yair, and C. Price, 2010: Lightning response to smoke from Amazonian fires. Geophys. Res. Lett., 37, L07801, https://doi.org/10.1029/2010GL042679.

- _ - — L L. Remer, and E. Hirsch, 2014: Cloud invigoration by aerosols-Coupling between microphysics and dynamics. Atmos. Res., 140, 38-60, https://doi.org/10.1016/ j.atmosres.2014.01.009.

Andreae, M. O., 2009: Correlation between cloud condensation nuclei concentration and aerosol optical thickness in remote and polluted regions. Atmos. Chem. Phys., 9, 543-556, https:// doi.org/10.5194/acp-9-543-2009.

— D. Rosenfeld, P. Artaxo, A. A. Costa, G. P. Frank, K. M. Longo, and M. A. F. Silva-Dias, 2004: Smoking rain clouds over the Amazon. Science, 303, 1337-1342, https://doi.org/ 10.1126/science. 1092779 .

Atlas, E., and C. Giam, 1988: Ambient concentration and precipitation scavenging of atmospheric organic pollutants. Water Air Soil Pollut., 38, 19-36.

Blakeslee, R. J., D. M. Mach, M. G. Bateman, and J. C. Bailey, 2014: Seasonal variations in the lightning diurnal cycle and implications for the global electric circuit. Atmos. Res., 135, 228-243, https://doi.org/10.1016/j.atmosres.2012.09.023.

Bringi, V., K. Knupp, A. Detwiler, L. Liu, I. Caylor, and R. Black, 1997: Evolution of a Florida thunderstorm during the Convection and Precipitation/Electrification Experiment: The case of 9 August 1991. Mon. Wea. Rev., 125, 2131-2160, https:// doi.org/10.1175/1520-0493(1997)125<2131:EOAFTD>2.0.CO;2.

Byers, H. R., and R. R. Braham, 1949: The Thunderstorm: Report of the Thunderstorm Project. U.S. Government Printing Office, $287 \mathrm{pp}$.

Carey, L. D., and S. A. Rutledge, 1996: A multiparameter radar case study of the microphysical and kinematic evolution of a lightning producing storm. Meteor. Atmos. Phys., 59, 33-64, https://doi.org/10.1007/BF01032000.

— lightning in tropical island convection: A C-band polarimetric radar study. Mon. Wea. Rev., 128, 2687-2710, https://doi.org/ 10.1175/1520-0493(2000)128<2687:TRBPAL > 2.0.CO;2.

Cecil, D. J., D. E. Buechler, and R. J. Blakeslee, 2014: Gridded lightning climatology from TRMM-LIS and OTD: Dataset description. Atmos. Res., 135, 404-414, https://doi.org/10.1016/ j.atmosres.2012.06.028.

Chmielewski, V. C., and E. C. Bruning, 2016: Lightning Mapping Array flash detection performance with variable receiver thresholds. J. Geophys. Res. Atmos., 121, 8600-8614, https:// doi.org/10.1002/2016JD025159.

Christian, H. J., and Coauthors, 2003: Global frequency and distribution of lightning as observed from space by the Optical Transient Detector. J. Geophys. Res., 108, 4005, https:// doi.org/10.1029/2002JD002347.

Chu, D., Y. Kaufman, C. Ichoku, L. Remer, D. Tanré, and B. Holben, 2002: Validation of MODIS aerosol optical depth retrieval over land. Geophys. Res. Lett., 29, 1617, https:// doi.org/10.1029/2001GL013205.

Coquillat, S., M.-P. Boussaton, M. Buguet, D. Lambert, J.-F. Ribaud, and A. Berthelot, 2013: Lightning ground flash patterns over Paris area between 1992 and 2003: Influence of pollution? Atmos. Res., 122, 77-92, https://doi.org/10.1016/ j.atmosres.2012.10.032.

Curran, E. B., R. L. Holle, and R. E. López, 2000: Lightning casualties and damages in the United States from 1959 to 1994. J. Climate, 13, 3448-3464, https://doi.org/10.1175/1520-0442(2000) 013<3448:LCADIT>2.0.CO;2. 
Dee, D., and Coauthors, 2011: The ERA-Interim reanalysis: Configuration and performance of the data assimilation system. Quart. J. Roy. Meteor. Soc., 137, 553-597, https://doi.org/10.1002/qj.828.

Deierling, W., and W. A. Petersen, 2008: Total lightning activity as an indicator of updraft characteristics. J. Geophys. Res., 113, D16210, https://doi.org/10.1029/2007JD009598.

,-- J. Latham, S. Ellis, and H. J. Christian, 2008: The relationship between lightning activity and ice fluxes in thunderstorms. J. Geophys. Res., 113, D15210, https://doi.org/ 10.1029/2007JD009700.

Dye, J., and Coauthors, 1986: Early electrification and precipitation development in a small, isolated Montana cumulonimbus. J. Geophys. Res., 91, 1231-1247, https://doi.org/ 10.1029/JD091iD01p01231.

Emanuel, K. A., 1994: Atmospheric Convection. Oxford University Press, $580 \mathrm{pp}$.

Fan, J., and Coauthors, 2009: Dominant role by vertical wind shear in regulating aerosol effects on deep convective clouds. J. Geophys. Res., 114, D22206, https://doi.org/10.1029/2009JD012352.

_ D. Dosenfeld, Y. Yang, C. Zhao, L. R. Leung, and Z. Li, 2015: Substantial contribution of anthropogenic air pollution to catastrophic floods in southwest China. Geophys. Res. Lett., 42, 6066-6075, https://doi.org/10.1002/2015GL064479.

Feingold, G., 2003: First measurements of the Twomey indirect effect using ground-based remote sensors. Geophys. Res. Lett., 30, 1287, https://doi.org/10.1029/2002GL016633.

Fierro, A. O., E. R. Mansell, D. R. MacGorman, and C. L. Ziegler, 2013: The implementation of an explicit charging and discharge lightning scheme within the WRF-ARW model: Benchmark simulations of a continental squall line, a tropical cyclone, and a winter storm. Mon. Wea. Rev., 141, 2390-2415, https://doi.org/10.1175/MWR-D-12-00278.1.

Gatlin, P. N., and S. J. Goodman, 2010: A total lightning trending algorithm to identify severe thunderstorms. J. Atmos. Oceanic Technol., 27, 3-22, https://doi.org/ 10.1175/2009JTECHA1286.1.

Goodman, S. J., D. E. Buechler, P. D. Wright, and W. D. Rust, 1988: Lightning and precipitation history of a microburstproducing storm. Geophys. Res. Lett., 15, 1185-1188, https:// doi.org/10.1029/GL015i011p01185.

__ , and Coauthors, 2005: The North Alabama lightning mapping array: Recent severe storm observations and future prospects. Atmos. Res., 76, 423-437, https://doi.org/10.1016/ j.atmosres.2004.11.035.

Hales, J. M., and M. T. Dana, 1979: Precipitation scavenging of urban pollutants by convective storm systems. J. Appl. Meteor., 18, 294-316, https://doi.org/10.1175/1520-0450(1979) 018<0294:PSOUPB $>2.0 . \mathrm{CO} ; 2$.

Harris, R. J., J. R. Mecikalski, W. M. MacKenzie Jr., P. A. Durkee, and K. E. Nielsen, 2010: The definition of GOES infrared lightning initiation interest fields. J. Appl. Meteor. Climatol., 49, 2527-2543, https://doi.org/10.1175/2010JAMC2575.1.

He, Q., C. Li, J. Mao, A. K.-H. Lau, and D. A. Chu, 2008: Analysis of aerosol vertical distribution and variability in Hong Kong. J. Geophys. Res., 113, D14211, https://doi.org/10.1029/ 2008JD009778.

Holben, B. N., and Coauthors, 1998: AERONET-A federated instrument network and data archive for aerosol characterization. Remote Sens. Environ., 66, 1-16, https://doi.org/ 10.1016/S0034-4257(98)00031-5.

Holle, R. L., 2016: A summary of recent national-scale lightning fatality studies. Wea. Climate Soc., 8, 35-42, https://doi.org/ 10.1175/WCAS-D-15-0032.1.
— A. I. Watson, R. E. López, D. R. Macgorman, R. Ortiz, and W. D. Otto, 1994: The life cycle of lightning and severe weather in a 3-4 June 1985 PRE-STORM mesoscale convective system. Mon. Wea. Rev., 122, 1798-1808, https://doi.org/ 10.1175/1520-0493(1994)122<1798:TLCOLA > 2.0.CO;2.

Ichoku, C., D. A. Chu, S. Mattoo, Y. J. Kaufman, L. A. Remer, D. Tanré, I. Slutsker, and B. N. Holben, 2002: A spatiotemporal approach for global validation and analysis of MODIS aerosol products. Geophys. Res. Lett., 29, 1616, https://doi.org/10.1029/2001GL013206.

Jackson, J. M., H. Liu, I. Laszlo, S. Kondragunta, L. A. Remer, J. Huang, and H. C. Huang, 2013: Suomi-NPP VIIRS aerosol algorithms and data products. J. Geophys. Res. Atmos., 118, 12 673-12 689, https://doi.org/10.1002/2013JD020449.

Jacobson, E. A., and E. P. Krider, 1976: Electrostatic field changes produced by Florida lightning. J. Atmos. Sci., 33, 103-117, https://doi.org/10.1175/1520-0469(1976)033<0103: $\mathrm{EFCPBF}>2.0 . \mathrm{CO} ; 2$.

Jin, M., J. M. Shepherd, and M. D. King, 2005: Urban aerosols and their variations with clouds and rainfall: A case study for New York and Houston. J. Geophys. Res., 110, D10S20, https://doi.org/10.1029/2004JD005081.

Kar, S. K., Y. A. Liou, and K. J. Ha, 2009: Aerosol effects on the enhancement of cloud-to-ground lightning over major urban areas of South Korea. Atmos. Res., 92, 80-87, https://doi.org/ 10.1016/j.atmosres.2008.09.004.

Khain, A., D. Rosenfeld, and A. Pokrovsky, 2005: Aerosol impact on the dynamics and microphysics of deep convective clouds. Quart. J. Roy. Meteor. Soc., 131, 2639-2663, https://doi.org/ 10.1256/qj.04.62.

Konrad, C. E., 1997: Synoptic-scale features associated with warm season heavy rainfall over the interior southeastern United States. Wea. Forecasting, 12, 557-571, https://doi.org/10.1175/ 1520-0434(1997)012<0557:SSFAWW $>2.0 . C O ; 2$.

Koshak, W., and Coauthors, 2004: North Alabama Lightning Mapping Array (LMA): VHF source retrieval algorithm and error analyses. J. Atmos. Oceanic Technol., 21, 543-558, https://doi.org/10.1175/1520-0426(2004)021<0543: NALMAL $>2.0 . \mathrm{CO} ; 2$.

Kovacs, T., 2006: Comparing MODIS and AERONET aerosol optical depth at varying separation distances to assess groundbased validation strategies for spaceborne lidar. J. Geophys. Res., 111, D24203, https://doi.org/10.1029/2006JD007349.

Krehbiel, P. R., R. J. Thomas, W. Rison, T. Hamlin, J. Harlin, and M. Davis, 2000: GPS-based mapping system reveals lightning inside storms. Eos, Trans. Amer. Geophys. Union, 81, 21-25, https://doi.org/10.1029/00EO00014.

Larsen, H., and E. Stansbury, 1974: Association of lightning flashes with precipitation cores extending to height $7 \mathrm{~km}$. J. Atmos. Terr. Phys., 36, 1547-1548, https://doi.org/10.1016/ 0021-9169(74)90232-3.

Lee, S. S., and G. Feingold, 2010: Precipitating cloud-system response to aerosol perturbations. Geophys. Res. Lett., 37, L23806, https://doi.org/10.1029/2010GL045596.

Levy, R. C., L. A. Remer, and O. Dubovik, 2007a: Global aerosol optical properties and application to Moderate Resolution Imaging Spectroradiometer aerosol retrieval over land. J. Geophys. Res., 112, D13210, https://doi.org/10.1029/ 2006JD007815.

_ - _ S. Mattoo, E. F. Vermote, and Y. J. Kaufman, 2007b: Second-generation operational algorithm: Retrieval of aerosol properties over land from inversion of Moderate Resolution Imaging Spectroradiometer spectral reflectance. 
J. Geophys. Res., 112, D13211, https://doi.org/10.1029/ 2006JD007811.

, S. Mattoo, L. A. Munchak, L. A. Remer, A. M. Sayer, F. Patadia, and N. C. Hsu, 2013: The Collection 6 MODIS aerosol products over land and ocean. Atmos. Meas. Tech., 6, 2989-3034, https://doi.org/10.5194/amt-6-2989-2013.

Li, L. F., W. H. Li, and Y. Kushnir, 2012: Variation of the North Atlantic subtropical high western ridge and its implication to southeastern US summer precipitation. Climate Dyn., 39, 1401-1412, https://doi.org/10.1007/s00382-011-1214-y.

Liu, C. T., E. J. Zipser, and S. W. Nesbitt, 2007: Global distribution of tropical deep convection: Different perspectives from TRMM infrared and radar data. J. Climate, 20, 489-503, https://doi.org/10.1175/JCLI4023.1.

Liu, P. F., and Coauthors, 2011: Hygroscopic properties of aerosol particles at high relative humidity and their diurnal variations in the North China Plain. Atmos. Chem. Phys., 11, 3479-3494, https://doi.org/10.5194/acp-11-3479-2011.

Liu, Y., M. Franklin, R. Kahn, and P. Koutrakis, 2007: Using aerosol optical thickness to predict ground-level PM 2.5 concentrations in the St. Louis area: A comparison between MISR and MODIS. Remote Sens. Environ., 107, 33-44, https:// doi.org/10.1016/j.rse.2006.05.022.

Livingston, J., and Coauthors, 2009: Comparison of aerosol optical depths from the Ozone Monitoring Instrument (OMI) on Aura with results from airborne sunphotometry, other space and ground measurements during MILAGRO/INTEX-B. Atmos. Chem. Phys., 9, 6743-6765, https://doi.org/10.5194/ acp-9-6743-2009.

MacGorman, D. R., and W. D. Rust, 1998: The Electrical Nature of Storms. Oxford University Press, $422 \mathrm{pp}$.

Mansell, E. R., and C. L. Ziegler, 2013: Aerosol effects on simulated storm electrification and precipitation in a two-moment bulk microphysics model. J. Atmos. Sci., 70, 2032-2050, https:// doi.org/10.1175/JAS-D-12-0264.1.

,-- , and E. C. Bruning, 2010: Simulated electrification of a small thunderstorm with two-moment bulk microphysics. J. Atmos. Sci., 67, 171-194, https://doi.org/10.1175/ 2009JAS2965.1.

Marshall, J., and S. Radhakant, 1978: Radar precipitation maps as lightning indicators. J. Appl. Meteor., 17, 206-212, https:// doi.org/10.1175/1520-0450(1978)017<0206:RPMALI>2.0.CO;2.

Martonchik, J. V., and D. J. Diner, 1992: Retrieval of aerosol optical properties from multi-angle satellite imagery. IEEE Trans. Geosci. Remote Sens., 30, 223-230, https://doi.org/ 10.1109/36.134073.

- — , R. A. Kahn, T. P. Ackerman, M. M. Verstraete, B. Pinty, and H. R. Gordon, 1998: Techniques for the retrieval of aerosol properties over land and ocean using multiangle imaging. IEEE Trans. Geosci. Remote Sens., 36, 1212-1227, https://doi.org/10.1109/36.701027.

McCaul, E. W., Jr., J. Bailey, J. Hall, S. Goodman, R. Blakeslee, and D. Buechler, 2005: A flash clustering algorithm for North Alabama Lightning Mapping Array data. Conf. on Meteorological Applications of Lightning Data, San Diego, CA, Amer. Meteor. Soc., 5.2, https://ams.confex.com/ams/Annual2005/ techprogram/paper_87989.htm.

_ _ S. J. Goodman, K. M. LaCasse, and D. J. Cecil, 2009: Forecasting lightning threat using cloud-resolving model simulations. Wea. Forecasting, 24, 709-729, https://doi.org/10.1175/ 2008WAF2222152.1.

Mecikalski, J. R., X. Li, L. D. Carey, E. W. McCaul Jr., and T. A. Coleman, 2013: Regional comparison of GOES cloud-top properties and radar characteristics in advance of first-flash lightning initiation. Mon. Wea. Rev., 141, 55-74, https:// doi.org/10.1175/MWR-D-12-00120.1.

Morales Rodriguez, C. A., R. P. da Rocha, and R. Bombardi, 2010: On the development of summer thunderstorms in the city of São Paulo: Mean meteorological characteristics and pollution effect. Atmos. Res., 96, 477-488, https://doi.org/10.1016/ j.atmosres.2010.02.007.

Mosier, R. M., C. Schumacher, R. E. Orville, and L. D. Carey, 2011: Radar nowcasting of cloud-to-ground lightning over Houston, Texas. Wea. Forecasting, 26, 199-212, https://doi.org/10.1175/ 2010WAF2222431.1.

Naccarato, K., O. Pinto, and I. Pinto, 2003: Evidence of thermal and aerosol effects on the cloud-to-ground lightning density and polarity over large urban areas of southeastern Brazil. Geophys. Res. Lett., 30, https://doi.org/10.1029/ 2003 GL017496.

Orville, R. E., and Coauthors, 2001: Enhancement of cloud-toground lightning over Houston, Texas. Geophys. Res. Lett., 28, 2597-2600, https://doi.org/10.1029/2001GL012990.

Phillips, J., M. Cane, and C. Rosenzweig, 1998: ENSO, seasonal rainfall patterns and simulated maize yield variability in Zimbabwe. Agric. For. Meteor., 90, 39-50, https://doi.org/ 10.1016/S0168-1923(97)00095-6.

Proestakis, E., S. Kazadzis, K. Lagouvardos, V. Kotroni, and A. Kazantzidis, 2016a: Lightning activity and aerosols in the Mediterranean region. Atmos. Res., 170, 66-75, https://doi.org/ 10.1016/j.atmosres.2015.11.010.

,,,,---- V. Amiridis, E. Marinou, C. Price, and A. Kazantzidis, 2016b: Aerosols and lightning activity: The effect of vertical profile and aerosol type. Atmos. Res., 182, 243-255, https://doi.org/10.1016/j.atmosres.2016.07.031.

Radke, L., and P. Hobbs, 1969: Measurement of cloud condensation nuclei, light scattering coefficient, sodium-containing particles, and Aitken nuclei in the Olympic Mountains of Washington. J. Atmos. Sci., 26, 281-288, https://doi.org/10.1175/ 1520-0469(1969)026<0281:MOCCNL>2.0.CO;2.

Reap, R. M., 1994: Analysis and prediction of lightning strike distributions associated with synoptic map types over Florida. Mon. Wea. Rev., 122, 1698-1715, https://doi.org/ 10.1175/1520-0493(1994)122<1698:AAPOLS > 2.0.CO;2.

Rienecker, M. M., and Coauthors, 2011: MERRA: NASA's Modern-Era Retrospective Analysis for Research and Applications. J. Climate, 24, 3624-3648, https://doi.org/ 10.1175/JCLI-D-11-00015.1.

Rison, W., R. Thomas, P. Krehbiel, T. Hamlin, and J. Harlin, 1999: A GPS-based three-dimensional lightning mapping system: Initial observations in central New Mexico. Geophys. Res. Lett., 26, 3573-3576, https://doi.org/10.1029/1999GL010856.

Robe, F. R., and K. A. Emanuel, 2001: The effect of vertical wind shear on radiative-convective equilibrium states. J. Atmos. Sci., 58, 1427-1445, https://doi.org/10.1175/1520-0469(2001) 058<1427:TEOVWS $>2.0$. CO 2 .

Ropelewski, C. F., and M. S. Halpert, 1996: Quantifying Southern Oscillation-precipitation relationships. J. Climate, 9, 1043-1059, https://doi.org/10.1175/1520-0442(1996)009<1043: QSOPR $>2.0 . \mathrm{CO} ; 2$.

Rotunno, R., J. B. Klemp, and M. L. Weisman, 1988: A theory for strong, long-lived squall lines. J. Atmos. Sci., 45, 463-485, https:// doi.org/10.1175/1520-0469(1988)045<0463:ATFSLL>2.0.CO;2.

Saide, P., and Coauthors, 2015: Central American biomass burning smoke can increase tornado severity in the U.S. Geophys. Res. Lett., 42, 956-965, https://doi.org/10.1002/2014GL062826. 
Saunders, C., H. Bax-Norman, C. Emersic, E. Avila, and N. Castellano, 2006: Laboratory studies of the effect of cloud conditions on graupel/crystal charge transfer in thunderstorm electrification. Quart. J. Roy. Meteor. Soc., 132, 2653-2673, https://doi.org/10.1256/qj.05.218.

Schultz, C. J., W. A. Petersen, and L. D. Carey, 2011: Lightning and severe weather: A comparison between total and cloud-toground lightning trends. Wea. Forecasting, 26, 744-755, https:// doi.org/10.1175/WAF-D-10-05026.1.

— L. D. Carey, E. V. Schultz, and R. J. Blakeslee, 2017: Kinematic and microphysical significance of lightning jumps versus nonjump increases in total flash rate. Wea. Forecasting, 32, 275-288, https://doi.org/10.1175/WAF-D-15-0175.1.

Shen, X. J., and Coauthors, 2011: First long-term study of particle number size distributions and new particle formation events of regional aerosol in the North China Plain. Atmos. Chem. Phys., 11, 1565-1580, https://doi.org/10.5194/acp-11-1565-2011.

Sihto, S.-L., and Coauthors, 2011: Seasonal variation of CCN concentrations and aerosol activation properties in boreal forest. Atmos. Chem. Phys., 11, 13 269-13 285, https://doi.org/ 10.5194/acp-11-13269-2011.

Smirnov, A., B. Holben, T. Eck, I. Slutsker, B. Chatenet, and R. Pinker, 2002: Diurnal variability of aerosol optical depth observed at AERONET (Aerosol Robotic Network) sites. Geophys. Res. Lett., 29, 2115, https://doi.org/10.1029/ 2002GL016305.

Steiger, S. M., R. E. Orville, and G. Huffines, 2002: Cloud-toground lightning characteristics over Houston, Texas: 19892000. J. Geophys. Res., 107, 4117, https://doi.org/10.1029/ 2001JD001142.

Stolz, D. C., S. A. Rutledge, and J. R. Pierce, 2015: Simultaneous influences of thermodynamics and aerosols on deep convection and lightning in the tropics. J. Geophys. Res. Atmos., 120, 6207-6231, https://doi.org/10.1002/2014JD023033.

, — — - - and S. C. Heever, 2017: A global lightning parameterization based on statistical relationships among environmental factors, aerosols, and convective clouds in the TRMM climatology. J. Geophys. Res. Atmos., 122, 7461-7492, https://doi.org/10.1002/2016JD026220.

Storer, R. L., S. C. van den Heever, and G. L. Stephens, 2010: Modeling aerosol impacts on convective storms in different environments. J. Atmos. Sci., 67, 3904-3915, https://doi.org/ 10.1175/2010JAS3363.1.

— - - , and T. L'Ecuyer, 2014: Observations of aerosolinduced convective invigoration in the tropical east Atlantic. J. Geophys. Res. Atmos., 119, 3963-3975, https://doi.org/ 10.1002/2013JD020272.

Tan, Y., L. Peng, Z. Shi, and H. Chen, 2016: Lightning flash density in relation to aerosol over Nanjing (China). Atmos. Res., 174, 1-8, https://doi.org/10.1016/j.atmosres.2016.01.009.

Thomas, R. J., P. R. Krehbiel, W. Rison, S. J. Hunyady, W. P. Winn, T. Hamlin, and J. Harlin, 2004: Accuracy of the lightning mapping array. J. Geophys. Res., 109, D14207, https:// doi.org/10.1029/2004JD004549.

Thornton, J. A., K. S. Virts, R. H. Holzworth, and T. P. Mitchell, 2017: Lightning enhancement over major oceanic shipping lanes. Geophys. Res. Lett., 44, 9102-9111, https://doi.org/ 10.1002/2017GL074982.

van den Heever, S. C., and W. R. Cotton, 2007: Urban aerosol impacts on downwind convective storms. J. Appl. Meteor. Climatol., 46, 828-850, https://doi.org/10.1175/JAM2492.1.

, G. G. Carrió, W. R. Cotton, P. J. DeMott, and A. J. Prenni, 2006: Impacts of nucleating aerosol on Florida storms. Part I:
Mesoscale simulations. J. Atmos. Sci., 63, 1752-1775, https:// doi.org/10.1175/JAS3713.1.

Van Donkelaar, A., R. V. Martin, R. C. Levy, A. M. da Silva, M. Krzyzanowski, N. E. Chubarova, E. Semutnikova, and A. J. Cohen,, 2011: Satellite-based estimates of ground-level fine particulate matter during extreme events: A case study of the Moscow fires in 2010. Atmos. Environ., 45, 6225-6232, https:// doi.org/10.1016/j.atmosenv.2011.07.068.

Vincent, B. R., L. D. Carey, D. Schneider, K. Keeter, and R. Gonski, 2004: Using WSR-88D reflectivity data for the prediction of cloud-to-ground lightning: A central North Carolina study. Natl. Wea. Dig., 27, 35-44.

Wang, Y., Q. Wan, W. Meng, F. Liao, H. Tan, and R. Zhang, 2011: Long-term impacts of aerosols on precipitation and lightning over the Pearl River delta megacity area in China. Atmos. Chem. Phys., 11, 12 421-12 436, https://doi.org/10.5194/acp-1112421-2011.

- and Coauthors, 2014: Assessing the effects of anthropogenic aerosols on Pacific storm track using a multiscale global climate model. Proc. Natl. Acad. Sci. USA, 111, 6894-6899, https://doi.org/10.1073/pnas.1403364111.

Weisman, M. L., and J. B. Klemp, 1982: The dependence of numerically simulated convective storms on vertical wind shear and buoyancy. Mon. Wea. Rev., 110, 504-520, https:// doi.org/10.1175/1520-0493(1982)110<0504:TDONSC > 2.0.CO;2.

Williams, E. R., and S. J. Heckman, 1993: The local diurnal variation of cloud electrification and the global diurnal variation of negative charge on the Earth. J. Geophys. Res., 98, 52215234, https://doi.org/10.1029/92JD02642.

, and G. Satori, 2004: Lightning, thermodynamic and hydrological comparison of the two tropical continental chimneys. J. Atmos. Sol.-Terr. Phys., 66, 1213-1231, https://doi.org/ 10.1016/j.jastp.2004.05.015.

_ - M. Weber, and R. Orville, 1989: The relationship between lightning type and convective state of thunderclouds. J. Geophys. Res., 94, 13 213-13 220, https://doi.org/10.1029/ JD094iD11p13213.

- R. Zhang, and J. Rydock, 1991: Mixed-phase microphysics and cloud electrification. J. Atmos. Sci., 48, 2195-2203, https:// doi.org/10.1175/1520-0469(1991)048<2195:MPMACE >2.0.CO;2. , and Coauthors, 2002: Contrasting convective regimes over the Amazon: Implications for cloud electrification. J. Geophys. Res., 107, 8082, https://doi.org/10.1029/2001JD000380.

$\mathrm{Wu}, \mathrm{X}$., and M. Yanai, 1994: Effects of vertical wind shear on the cumulus transport of momentum: Observations and parameterization. J. Atmos. Sci., 51, 1640-1660, https://doi.org/ 10.1175/1520-0469(1994)051<1640:EOVWSO > 2.0.CO;2.

Yuan, T., and Coauthors, 2012: Aerosol indirect effect on tropospheric ozone via lightning. J. Geophys. Res., 117, D18213, https://doi.org/10.1029/2012JD017723.

, L. A. Remer, K. E. Pickering, and H. Yu, 2011: Observational evidence of aerosol enhancement of lightning activity and convective invigoration. Geophys. Res. Lett., 38, L04701, https://doi.org/10.1029/2010GL046052.

Zipser, E. J., 1994: Deep cumulonimbus cloud systems in the tropics with and without lightning. Mon. Wea. Rev., 122, 1837-1851, https://doi.org/10.1175/1520-0493(1994)122<1837: DCCSIT $>2.0 . \mathrm{CO} ; 2$.

, and K. R. Lutz, 1994: The vertical profile of radar reflectivity of convective cells: A strong indicator of storm intensity and lightning probability? Mon. Wea. Rev., 122, 1751-1759, https://doi.org/10.1175/1520-0493(1994)122<1751:TVPORR>2.0. $\mathrm{CO} ; 2$. 